\title{
Leaf wax $n$-alkane distributions record ecological changes during the Younger Dryas at Trzechowskie paleolake (northern Poland) without temporal delay
}

\author{
Bernhard Aichner $^{1}$, Florian Ott ${ }^{2,3}$, Michał Słowiński ${ }^{4}$, Agnieszka M. Noryśkiewicz ${ }^{5}$, Achim Brauer ${ }^{2}$, and \\ Dirk Sachse ${ }^{6}$ \\ ${ }^{1}$ Institute of Earth and Environmental Sciences, University of Potsdam, 14476 Potsdam-Golm, Germany \\ ${ }^{2}$ Section 5.2: Climate Dynamics and Landscape Evolution, GFZ German Research Centre for \\ Geosciences, 14473 Potsdam, Germany \\ ${ }^{3}$ Department of Archaeology, Max Planck Institute for the Science of Human History, 07745 Jena, Germany \\ ${ }^{4}$ Department of Environmental Resources and Geohazards, Institute of Geography and Spatial Organisation, Polish Academy \\ of Sciences, 00-818 Warsaw, Poland \\ ${ }^{5}$ Institute of Archaeology, Faculty of History, Nicolaus Copernicus University, 87-100 Toruń, Poland \\ ${ }^{6}$ Organic Surface Geochemistry Lab, Section 5.1: Geomorphology, GFZ German Research Centre for \\ Geosciences, 14473 Potsdam, Germany
}

Correspondence: Bernhard Aichner (bernhard.aichner@gmx.de)

Received: 5 February 2018 - Discussion started: 19 March 2018

Revised: 18 June 2018 - Accepted: 30 September 2018 - Published: 2 November 2018

\begin{abstract}
While of higher plant origin, a specific source assignment of sedimentary leaf wax $n$-alkanes remains difficult. In addition, it is unknown how fast a changing catchment vegetation would be reflected in sedimentary leaf wax archives. In particular, for a quantitative interpretation of $n$ alkane $\mathrm{C}$ and $\mathrm{H}$ isotope ratios in terms of paleohydrological and paleoecological changes, a better understanding of transfer times and dominant sedimentary sources of leaf wax $n$-alkanes is required.

In this study we tested to what extent compositional changes in leaf wax $n$-alkanes can be linked to known vegetation changes by comparison with high-resolution palynological data from the same archive. We analyzed leaf wax $n$-alkane concentrations and distributions in decadal resolution from a sedimentary record from Trzechowskie paleolake (TRZ, northern Poland), covering the Late Glacial to early Holocene (13 360-9940 yr BP). As an additional source indicator of targeted $n$-alkanes, compound-specific carbon isotopic data have been generated in lower time resolution. The results indicated rapid responses of $n$-alkane distribution patterns coinciding with major climatic and paleoecological transitions. We found a shift towards higher average chain length (ACL) values at the Allerød-Younger
\end{abstract}

Dryas (YD) transition between 12680 and $12600 \mathrm{yr} \mathrm{BP}$, coevaled with a decreasing contribution of arboreal pollen (mainly Pinus and Betula) and a subsequently higher abundance of pollen derived from herbaceous plants (Poaceae, Cyperaceae, Artemisia), shrubs, and dwarf shrubs (Juniperus and Salix). The termination of the YD was characterized by a successive increase in $n$-alkane concentrations coinciding with a sharp decrease in ACL values between 11580 and $11490 \mathrm{yr} \mathrm{BP}$, reflecting the expansion of woodland vegetation at the YD-Holocene transition. A gradual reversal to longer chain lengths after $11200 \mathrm{yr} \mathrm{BP}$, together with decreasing $n$-alkane concentrations, most likely reflects the early Holocene vegetation succession with a decline of $B e$ tula.

These results show that $n$-alkane distributions reflect vegetation changes and that a fast (i.e., subdecadal) signal transfer occurred. However, our data also indicate that a standard interpretation of directional changes in biomarker ratios remains difficult. Instead, responses such as changes in ACL need to be discussed in the context of other proxy data. In addition, we find that organic geochemical data integrate different ecological information compared to pollen, since some gymnosperm genera, such as Pinus, produce only a 
very low amount of $n$-alkanes and for this reason their contribution may be largely absent from biomarker records. Our results demonstrate that a combination of palynological and $n$-alkane data can be used to infer the major sedimentary leaf wax sources and constrain leaf wax transport times from the plant source to the sedimentary sink and thus pave the way towards quantitative interpretation of compound-specific hydrogen isotope ratios for paleohydrological reconstructions.

\section{Introduction}

In the past decades organic geochemical proxies, such as concentrations and ratios of $n$-alkanes derived from aquatic and terrestrial organisms, have increasingly been used as paleoecological indicators. These compounds have been postulated to be at least semi-source-specific for different groups of organisms, e.g., aquatic vs. terrestrial plants, trees vs. grasses, gymnosperms vs. angiosperms (e.g., Eglinton and Hamilton, 1967; Wakeham, 1976; Meyers and Ishiwatari, 1993; Ficken et al., 2000). Consequently, changes in $n$ alkane ratios in sedimentary records have frequently been interpreted to reflect changes in vegetation in lakes and their catchments (e.g., Schwark et al., 2002; Hanisch et al., 2003; Liu and Huang, 2005; Zhang et al., 2006; Nichols et al., 2006; Hockun et al., 2016). While most of these studies delivered plausible indications that the application of these proxies reliably reflect changes in local ecological conditions, a compilation of published plant leaf wax $n$-alkane data revealed that there is little agreement between specific $n$-alkanes and potential groups of source organisms, at least if considering a global data set (Bush and McInerney, 2013). Another important aspect is the variability of leaf wax concentrations, which appears to be high among different plants species (Diefendorf et al., 2011). This suggests that sedimentary $n$-alkanes rather reflect a signal biased towards strong leaf wax producers within the catchment instead of the average composition of vegetation. Finally, transit times from source to sink need to be considered. There is evidence for significant aging of leaf wax compounds, for example in soils, leading to potential lag times before deposition in sediments (Douglas et al., 2014; Gierga et al., 2016). These might differ from the transition times of plant pollen depending on the scale and type of the respective catchment (Feakins, 2013).

Here we focus on the transition from the Late Glacial to the Holocene, which was characterized by abrupt climatic and vegetation changes. After an initial warming phase (Bølling-Allerød) temperatures in western Europe rapidly dropped by ca. $4-6^{\circ} \mathrm{C}$ for ca. 1100 years, possibly caused by a reduction of the northern Atlantic meridional overturning circulation (AMOC) forced by meltwater input into the North Atlantic (McManus et al., 2004; Rasmussen et al., 2006; Denton et al., 2010; Elmore and Wright, 2011; Heiri et al., 2014; Renssen et al., 2015). This Younger Dryas cold period (YD) was originally defined by means of ecological changes in Europe inferred from lacustrine palynological records (Firbas, 1949; Iversen, 1973; Overbeck, 1975). Attempts to precisely date the onset and termination of this event included the establishment of chronologies based on annually laminated (varved) sediments anchored by tephra layers, such as the Laacher See Tephra (LST), Vedde Ash, Askja-S, or Hässeldalen (Brauer et al., 1999a, b; Goslar et al., 2000; Neugebauer et al., 2012; Lane et al., 2013; Wulf et al., 2013, 2016; Ott et al., 2016). For instance, by applying these techniques at Meerfelder Maar (MFM) in western Germany, the YD was dated to span from 12680-11590 yr BP (Brauer et al., 1999a, b). These studies have shown that vegetation changes in continental Europe at the YD onset were not synchronous with the cooling in Greenland (i.e., the onset of Greenland Stadial 1; GS-1) but occurred with a lag of ca. 100-170 years (Brauer et al., 1999b; Lane et al., 2013; Rach et al., 2014). By reconstructing hydrological conditions in western Germany using compound-specific hydrogen isotope analysis of biomarkers in subdecadal resolution, Rach et al. (2014) suggested that aridification occurring ca. 170 years after the onset of the cooling in Greenland was the main trigger for the vegetation response. As a potential cause, they suggest the expansion of sea ice and a consequent southward migration of the westerlies, which then transported cooler and drier air to Europe (Brauer et al., 2008). Schenk et al. (2018) emphasized the importance of the Fennoscandian ice sheet as an additional influencing factor on wind dynamics in the North Atlantic realm. Recently, Słowinski et al. (2017) found a further slight delay (20 years) of the ecological changes at the YD onset in the more continental parts of eastern Europe compared to western Germany based on pollen data from Trzechowskie paleolake (TRZ), northern Poland. Constraints about the termination of the YD are less precise. While Rach et al. (2014) observed a synchronous start of the Holocene in the MFM compared to Greenland ice cores, there is an ongoing debate about the timing and nature of short-term cooling events, sometimes referred to as pre-boreal oscillation (PBO) during the early Holocene (e.g., Björk et al., 1997; Bos et al., 2007; Ott et al., 2016).

In this study we analyze a ca. 3000-year record from northern Poland, which spans from the Allerød to the early Holocene and was sampled in ca. 10-year resolution. The principal aim was to test to what extent leaf wax $n$-alkane compositional changes in lacustrine sediments can be linked to vegetation changes by comparison with published highresolution palynological data from the same archive (Słowinski et al., 2017), which cover the Allerød to YD transition. Another goal was to evaluate possible differences in the transport pathways of pollen vs. leaf waxes, i.e., the identification of temporal leads or lags between leaf wax and pollen proxies. Further, we aim to establish a decadal, leafwax-based paleoecological record over the time period of the YD. 

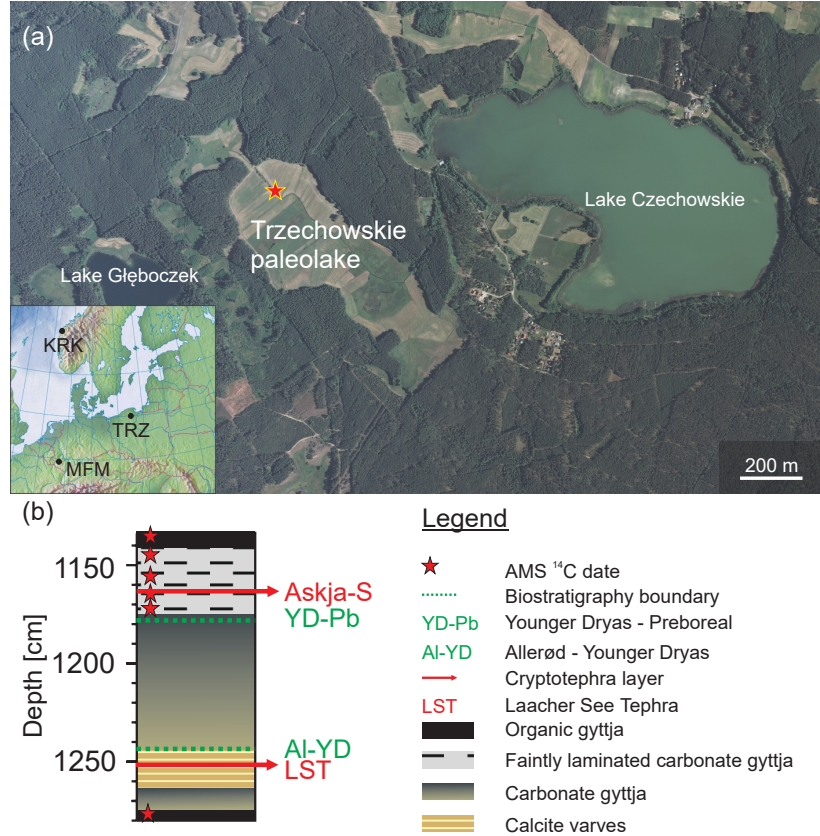

Figure 1. (a) Coring position (reddish yellow asterisk) at Trzechowskie paleolake (TRZ). (b) Schematic overview of sampled core section with anchor points used for the age model. LST: Laacher See Tephra. MFM: Meerfelder Maar. KRK: Lake Kråkenes.

\section{Study site}

The Trzechowskie paleolake (TRZ) is located in central northern Poland ca. $75 \mathrm{~km} \mathrm{SSW}$ of the city of Gdańsk (TRZ; $53^{\circ} 52.40^{\prime} \mathrm{N}, 18^{\circ} 12.930^{\prime} \mathrm{E}$; $110 \mathrm{~m}$ a.s.l.; Fig. 1) and developed after the retreat of the Late Weichselian ice sheet at ca. 15.8 cal kyr BP (Marks, 2012). It was formed by the successive melting of a buried ice block in a subglacial channel in the outwash plain of the Wda river and initially formed one large lake with still existing Lake Czechowskie (Słowiński, 2010; Błaszkiewicz et al., 2015; Słowiński et al., 2015). The paleolake maximum extension was approximately $1500 \times$ $450 \mathrm{~m}$ before it turned into peatland (transition from gyttja to peat at depth $183-182 \mathrm{~cm}$ dated to $3050 \pm 40 \mathrm{BP}$ ). Finally, in the late 19th century most of the former wetlands in this area were drained with the purpose of gaining agricultural grassland (Wulf et al., 2013; Słowinski et al., 2017). The present catchment is characterized by anthropogenic Pinus sylvestris forests. While spring and fall are characterized by alternating winds, major wind directions are low-speed westerlies during summers and easterlies during winters (Woś, 1999; Wulf et al., 2013). Mean annual precipitation and temperature are ca. $600 \mathrm{~mm}$ and $7{ }^{\circ} \mathrm{C}$, respectively (1981-1998 period; Kozłowska-Szczesna, 1993; Wójcik and Marciniak, 1993).

\section{Material and methods}

\subsection{Sampling and age model}

A $137 \mathrm{~cm}$ long core section $(1134-1271 \mathrm{~cm}$ of composite depth; Fig. 1b) was sampled in $0.5 \mathrm{~cm}$ intervals, except for the uppermost $17 \mathrm{~cm}$ and lowermost $10 \mathrm{~cm}$, which were sampled in $1 \mathrm{~cm}$ intervals. Within the laminated section (1244.5$1262 \mathrm{~cm}$ ), the sampling strategy was adjusted to obtain a 10year resolution (i.e., sampling of 10 varves), resulting in sample slices varying between 0.4 and $0.7 \mathrm{~cm}$ of thicknesses.

The age model was created with OxCal v4.2 (Bronk Ramsey, 2001, 2008; Bronk Ramsey and Lee, 2013) using a $P$ sequence model with variable $k$ parameter and the most recent radiocarbon calibration data set (IntCal13) (Reimer et al., 2013). The following age-anchor points have been used (Table 1): (a) five ${ }^{14} \mathrm{C}$ AMS radiocarbon dates calibrated with the Intcal13 data set (Reimer et al., 2013); (b) two tephra layers (Askja-S: $1164 \mathrm{~cm}, 11228 \pm 226 \mathrm{yr} \mathrm{BP}$, age from Ott et al., 2016; LST: $1253.75 \mathrm{~cm}, 12880 \pm 40 \mathrm{yr} \mathrm{BP}$, age from Brauer et al., 1999b); (c) varve chronology within the laminated section anchored by the LST (Wulf et al., 2013); and (d) two biostratigraphic changes at the YD onset (termination) characterized by a decrease (increase) in Pinus together with an abrupt increase (decrease) in non-arboreal pollen (NAP) and Juniperus. The latter were synchronized with similar shifts in nearby Lake Gosciaz $(1244 \mathrm{~cm}, 12650 \pm 70 \mathrm{yr} \mathrm{BP}$; $1183.5 \mathrm{~cm}, 11515 \pm 35 \mathrm{yr}$ BP; Litt et al., 2001), which are considered as the regional stratotype for the YD-Holocene boundary in northern Poland (Ralska-Jasiewiczowa et al., 1992; Litt et al., 2001; Ott et al., 2016).

The age model of this study (Fig. S1 in the Supplement) includes the Askja-S tephra and a biostratigraphic change (Ott et al., 2016) as additional early Holocene anchor points, resulting in a slightly different age model than published earlier by Słowinski et al. (2017). Pollen and macrofossil data from this paper were transferred to the updated age model. Since Słowinski et al. (2017) focused on a core section that covers the Allerød-YD transition (1230-1262 cm), offsets between the old and updated ages within that part of the core were minor, i.e., within the range of 5-15 years and restricted to the nonlaminated part at the YD onset (between 1230 and $1244.5 \mathrm{~cm})$.

\subsection{Biomarker extraction and quantification}

After freeze-drying and grinding with a mortar, the sediments were extracted for two cycles of $15 \mathrm{~min}$ with dichloromethane-methanol $(9: 1)$ using a Dionex ASE 350 accelerated solvent extraction system at $100{ }^{\circ} \mathrm{C}$ and 75 bar. $5 \alpha$-Androstane was spiked as an internal standard to the total lipid extract before the aliphatic fraction was eluted over silica gel (0.040-0.063 mesh) with $n$-hexane. The $n$-alkanes were separated and quantified relative to an internal standard using an Agilent 7890A gas chromatography (GC) instru- 
Table 1. Age-anchor points used for age-depth calibration of the studied core section (Słowinski et al., 2017). LST: Laacher See Tephra. Age from Brauer et al. (1999a). Askja-S age from Ott et al. (2016). Biostratigraphic age at the YD-Holocene transition from Ralska-Jasiewiczowa et al. (1992) and Litt et al. (2001). Age-depth plot of the age model in Fig. S1 in the Supplement.

\begin{tabular}{|c|c|c|c|c|c|}
\hline Lab code & $\begin{array}{l}\text { Composite } \\
\text { depth }(\mathrm{cm})\end{array}$ & Dated material/age-anchor point & $\begin{array}{r}\text { AMS }{ }^{14} \mathrm{C} \\
(\mathrm{yr} B P)\end{array}$ & $\begin{array}{r}\text { Calibrated age } \\
(\text { cal yr BP } \pm 2 \sigma)\end{array}$ & $\begin{array}{r}\text { Modeled age } \\
(\text { cal yr } \mathrm{BP} \pm 2 \sigma)\end{array}$ \\
\hline Poz-39366 & 1145 & $\begin{array}{l}\text { Pinus needle and bud scales, Betula sp. fruits } \\
\text { and bud scales }\end{array}$ & $8970 \pm 50$ & $10076 \pm 158$ & $10094 \pm 150$ \\
\hline GdA-3008 & 1156 & $\begin{array}{l}\text { Betula sp. fruits and bud scales, Pinus bud } \\
\text { scales }\end{array}$ & $9405 \pm 38$ & $10629 \pm 106$ & $10625 \pm 101$ \\
\hline- & 1164 & $\begin{array}{l}\text { varve-counted age of Askja-S tephra in Lake } \\
\text { Czechowskie }\end{array}$ & & $11228 \pm 226$ & \\
\hline GdA-3009 & 1165 & $\begin{array}{l}\text { Pinus needle and bud scales, Betula sp. fruits } \\
\text { and bud scales }\end{array}$ & $9587 \pm 38$ & $10938 \pm 187$ & $10934 \pm 169$ \\
\hline Poz-39367 & 1176 & $\begin{array}{l}\text { Betula sp. fruits and bud scales, Pinus needle } \\
\text { and bud scales }\end{array}$ & $9970 \pm 60$ & $11474 \pm 231$ & $11377 \pm 156$ \\
\hline- & 1183.5 & $\begin{array}{l}\text { biostratigraphic change; age information from } \\
\text { Lake Gosciaz }\end{array}$ & & $11515 \pm 35$ & \\
\hline GdA-3010* & 1241 & $\begin{array}{l}\text { Pinus bud scales, Betula sp. fruits and bud } \\
\text { scales }\end{array}$ & $10824 \pm 42$ & $12726 \pm 47^{*}$ & \\
\hline \multirow[t]{2}{*}{ GdA-3011* } & 1244 & $\begin{array}{l}\text { Betula sp. fruits and bud scales, Pinus needle } \\
\text { and bud scales }\end{array}$ & $10950 \pm 45$ & $12831 \pm 120^{*}$ & \\
\hline & 1244 & $\begin{array}{l}\text { biostratigraphic change; age information from } \\
\text { Lake Gosciaz }\end{array}$ & & $12650 \pm 70$ & \\
\hline- & 1244.5 & end varved sediments & & $12678 \pm 43$ & \\
\hline- & 1253.75 & varve-counted age of LST in the MFM record & & $12880 \pm 40$ & \\
\hline- & 1262 & begin varved sediments & & $13043 \pm 43$ & \\
\hline GdA-3012* & 1263 & $\begin{array}{l}\text { Pinus needle and bud scales, Betula sp. fruits } \\
\text { and bud scales }\end{array}$ & $11051 \pm 44$ & $12920 \pm 131^{*}$ & \\
\hline Poz-39369* & 1269 & $\begin{array}{l}\text { Pinus needle and bud scales, Dryas octopetala } \\
\text { - leaves, Betula sp. fruits and bud scales }\end{array}$ & $12040 \pm 70$ & $13914 \pm 169^{*}$ & \\
\hline GdA-3013 & 1276 & $\begin{array}{l}\text { Pinus needle, Betula sp. fruits and bud scales, } \\
\text { Betula nana leaves }\end{array}$ & $11718 \pm 47$ & $13576 \pm 137$ & $13522 \pm 94$ \\
\hline
\end{tabular}

* Indicates omitted ages.

ment equipped with an Agilent 5975C Series mass selective detector (MSD) system and flame ionization detection (FID; Agilent 7683B Series). $1 \mu \mathrm{L}$ of sample was injected onto a $30 \mathrm{~m}$ Restek DB-5 column $(30 \mathrm{~m}$, inner diameter $0.25 \mathrm{~mm}$, film thickness $0.25 \mu \mathrm{m}$ ). Temperature was programmed from $70-320^{\circ} \mathrm{C}$ at a rate of $12^{\circ} \mathrm{C} \mathrm{min}^{-1}$ (held $15 \mathrm{~min}$ ).

\subsection{Compound-specific carbon isotope analysis}

Compound-specific carbon isotopic values were measured using gas chromatography-isotope ratio mass spectrometry (GC-IRMS). We used a Thermo Scientific ${ }^{\circledR}$ trace gas chromatograph equipped with a Restek RTX-5 column (30 m, inner diameter $0.25 \mathrm{~mm}$, film thickness $0.25 \mu \mathrm{m}$ ) and a splitsplitless (SSL) injector operated in splitless mode with an evaporation temperature of $60^{\circ} \mathrm{C}$. The $\mathrm{GC}$ was connected via a GC isolink with a combustion furnace $\left(1000^{\circ} \mathrm{C}\right)$ and a ConFlo IV interface to a Delta V Plus isotope ratio mass spectrometer. Reference peaks of $\mathrm{CO}_{2}$ bracket target compound peaks during the course of a GC-IRMS run. Two of these peaks were used for the standardization of the isotopic analysis, while the remainders were treated as unknowns to assess precision. The precision of these replicates was better than 0.6\%o. Data were normalized to the Vienna Pee Dee Belemnite (VPBD) carbon isotopic scale by comparing them with an external standard containing $15 n$-alkane compounds ( $\mathrm{C}_{16}$ to $\mathrm{C}_{30}$ of known isotopic composition; $\mathrm{A} 5$ mix obtained from A. Schimmelmann, Indiana University, Bloomington). The root mean square error of replicate measurements of the standard across the course of analyses was below $0.7 \%$. Linearity of the IRMS system was monitored regularly by analyzing a B mix provided by A. Schimmelmann (i.e., $n$ alkanes with different concentrations). Samples were concentrated in order to achieve sufficient signal intensities of target compounds and only peaks within the linearity range $(>1000$ and $>10000 \mathrm{mV})$ were evaluated. 


\subsection{Alkane parameters and statistics}

Alkane parameters have been calculated using the following equations.

Average chain length (ACL): $\Sigma\left(\mathrm{C}_{n} \times n\right) / \Sigma\left(\mathrm{C}_{n}\right) ; \mathrm{C}_{n}$ : concentration of each $n$-alkane with $n$ carbon atoms.

Proxy for aquatic macrophytes ( $P_{\text {aq }}$; Ficken et al., 2000): $P_{\mathrm{aq}}=\left(n \mathrm{C}_{23}+n \mathrm{C}_{25}\right) /\left(n \mathrm{C}_{23}+n \mathrm{C}_{25}+n \mathrm{C}_{29}+n \mathrm{C}_{31}\right)$.

Before calculating Pearson correlation coefficients (PCCs) between $n$-alkane and pollen data, data have been $z$ transformed. Both data sets, consisting of 76 (n-alkanes) and 65 (pollen) data points, respectively, were transferred to equidistant time series with 65 data points using the zoo and simecol packages in R Studio. PCCs were calculated in SPSS.

\section{Results}

Aliphatic lipids in the samples were dominated by odd-chain $\mathrm{C}_{23}, \mathrm{C}_{25}, \mathrm{C}_{27}, \mathrm{C}_{29}$, and $\mathrm{C}_{31} n$-alkanes, with $n \mathrm{C}_{27}$ as the most abundant compound in all samples. The summed concentrations of these five compounds ranged between 3 and $263 \mu \mathrm{g}$ (g dry weight $)^{-1}$ (d.w.). Highest concentrations were measured before ca. $12600 \mathrm{yr}$ BP and between ca. 11300 and $10400 \mathrm{yr}$ BP (Fig. 2). The top of the studied core interval was marked by a $4 \mathrm{~cm}$ thick organic-rich layer (Fig. 1b), which was characterized by enhanced $n$-alkane concentrations but unchanged $n$-alkane patterns.

Throughout the record, we observed significant changes in the relative abundances of target compounds, resulting in pronounced shifts of related parameters such as ACL, $P_{\mathrm{aq}}$, and $n$-alkane ratios $n \mathrm{C}_{27} /\left(n \mathrm{C}_{27}+n \mathrm{C}_{29}\right)$ and $n \mathrm{C}_{27} /\left(n \mathrm{C}_{27}+\right.$ $\left.n \mathrm{C}_{31}\right) n \mathrm{C}_{29} /\left(n \mathrm{C}_{29}+n \mathrm{C}_{31}\right)$. For instance, ACL significantly increased between ca. 12680 and 12600 and decreased between 11580 and $11490 \mathrm{yr}$ BP. Minor oscillations of these indices were observed during the Allerød and early Holocene.

20 samples were analyzed for carbon isotope ratios (expressed as $\delta^{13} \mathrm{C}$ values). These values were relatively constant (ca. $-33 \%$ ) for the $n \mathrm{C}_{31}$ alkane, while $n \mathrm{C}_{29} \delta^{13} \mathrm{C}$ values became slightly more positive (up to $-31.5 \%$ ) throughout the studied interval (12 650-11200 yr BP). Other $n$-alkanes were characterized by increasing enrichment in ${ }^{13} \mathrm{C}$ (higher $\delta^{13} \mathrm{C}$ values) with decreasing chain length between ca. 12600 and $11600 \mathrm{yr}$ BP. The highest $\delta^{13} \mathrm{C}$ values $\left(-28 \%\right.$ o were measured for $n \mathrm{C}_{23}$ at ca. $11900 \mathrm{yr}$ BP. Data for $n$-alkane concentrations and $\delta^{13} \mathrm{C}$ values can be found in Tables S1 and S2 in the Supplement.

\section{Discussion}

\subsection{Sources of $n$-alkanes}

\subsubsection{Potential and constraints of $n$-alkane-based proxies}

Sedimentary leaf wax $n$-alkane sources can be broadly distinguished based on $n$-alkane chain length. Principally, midchain alkanes $\left(n \mathrm{C}_{23}\right.$ and $\left.n \mathrm{C}_{25}\right)$ are mostly attributed to aquatic sources or Sphagnum species, while long-chain compounds can be derived from terrestrial plants or emergent macrophytes (Eglinton and Hamilton, 1967; Baas et al., 2000; Ficken et al., 2000). In addition, it has been postulated that $n \mathrm{C}_{31}$ is indicative of grasses as trees preferably synthesize $n \mathrm{C}_{27}$ and $n \mathrm{C}_{29}$ alkanes. Consequently, the ratios of these compounds, such as $n \mathrm{C}_{27}$ vs. $n \mathrm{C}_{31}$, have frequently been applied in sedimentary archives to infer ecological changes in lake catchments such as shifts from grassland to trees (Meyers and Ishiwatari, 1993; Schwark et al., 2002; Meyers, 2003).

Nevertheless, an increasing number of studies have indicated that alkane patterns of plants are heterogeneous and compound distributions often overlap. For example, in some environments so-called "aquatic" mid-chain compounds ( $n \mathrm{C}_{23}$ and $n \mathrm{C}_{25}$ ) have been shown to be derived partly from terrestrial sources (Aichner et al., 2010a; Gao et al., 2011), while long-chain "terrestrial" compounds $\left(n \mathrm{C}_{27}\right.$ and $n \mathrm{C}_{29}$ ) were derived mainly from aquatic sources (Liu et al., 2015). Further, compilations of global plant data sets clearly indicate that indices such as ACL and long-chain nalkane ratios do not reliably reflect classes of terrestrial vegetation (Bush and McInerney, 2013). In addition, the sedimentary $n$-alkane pattern will be dominated by plants producing and delivering the largest amount of $n$-alkanes into the sedimentary sink. Based on a large-scale survey of different tree species, Diefendorf et al. (2011) found that angiosperms showed a tendency to produce higher concentrations of $n$ alkane leaf wax lipids compared to gymnosperms, a result later confirmed by Bush and McInerney (2013).

\subsubsection{Carbon isotopes as source indicators}

Source allocation of $n$-alkane homologues can also be inferred from their carbon isotope composition. For instance, in West African lakes with catchments dominated by $\mathrm{C}_{4}$ vegetation, only $n \mathrm{C}_{31}$ alkanes showed a $\mathrm{C}_{4}$ isotopic signal. In contrast, other long-chain $n$-alkanes carried a $\mathrm{C}_{3}$ plant signature (Garcin et al., 2014), likely resulting from higher $n$ alkane production in the few $\mathrm{C}_{3}$ trees in the lake catchment compared to the dominating $\mathrm{C}_{4}$ grasses. While no $\mathrm{C}_{4}$ plants were present in eastern Europe, aquatic plants are also characterized by more positive $\delta^{13} \mathrm{C}$ values (Allen and Spence, 1981; Keeley and Sandquist, 1992; Ficken et al., 2000; Mead et al., 2005; Aichner et al., 2010a), and an aquatic origin of mid- and long-chain $n$-alkanes can be confirmed or rejected: 


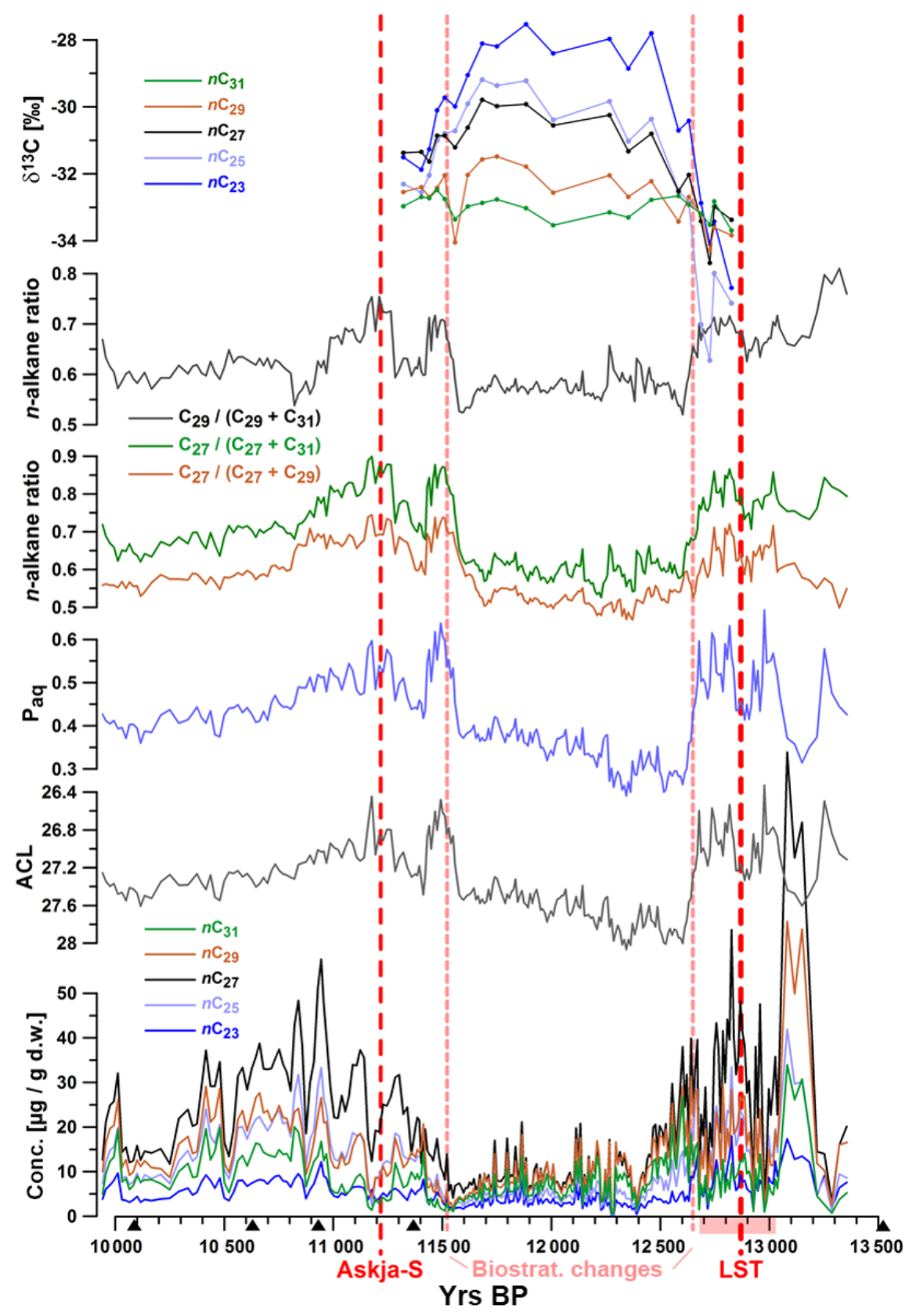

Figure 2. Concentrations of $n$-alkanes, average chain length (ACL), $P_{\mathrm{aq}}, n$-alkane ratios, and $\delta^{13} \mathrm{C}$ values plotted versus age. Red dotted lines mark occurrences of tephra layers Askja-S (A-S: $11228 \pm 226 \mathrm{yr}$ BP) and the Laacher See Tephra (LST $12880 \pm 40 \mathrm{yr}$ BP) and the biostratigraphic change at $1183.5 \mathrm{~cm}$ of depth $(11515 \pm 35 \mathrm{yr}$ BP $)$. Black triangles mark ${ }^{14} \mathrm{C}$ AMS ages. The pink shaded interval on the $x$ axis illustrates the laminated core section.

the constant $\delta^{13} \mathrm{C}$ values of ca. $-33 \%$ for $n \mathrm{C}_{31}$ and slightly more variable values for $n \mathrm{C}_{29}$ in our data set from TRZ paleolake suggest a stable terrestrial $\mathrm{C}_{3}$ vegetation source for these compounds (Meyers, and Ishiwatari, 1993; Meyer, 2003) during the study period. The ${ }^{13} \mathrm{C}$ enrichment in $n \mathrm{C}_{23}$, $n \mathrm{C}_{25}$, and $n \mathrm{C}_{27}$ during the YD could be explained by (a) a change in the sources of these compounds or (b) limited $\mathrm{CO}_{2}$ availability to potential aquatic sources. The latter could be induced by low atmospheric $p \mathrm{CO}_{2}$ or by the establishment of diffusion barriers such as ice cover and/or a thickened boundary layer in stagnant water. $\mathrm{CO}_{2}$ limitation due to enhanced aquatic productivity, higher water temperature, salinity, or pH can be excluded (Street-Perrott et al., 2004; Aichner et al., 2010a, b). More positive $\delta^{13} \mathrm{C}$ values could also result from a reduced isotopic fractionation of terrestrial plants subjected to water stress (Farquhar, 1989), in particular during the YD, 
when $8 \%-15 \%$ lower humidities have been reconstructed at MFM (Rach et al., 2014, 2017). On the other hand, all terrestrial plants would be affected by increased aridity, which should be reflected in all $n$-alkane homologues, contrary to our observations.

\subsubsection{Comparison with palynological proxies}

Mid-chain $n$-alkanes $\left(n \mathrm{C}_{23}, n \mathrm{C}_{25}\right)$

Concentrations of mid-chain-length compounds were low throughout the whole record. For instance, $n \mathrm{C}_{23}$ exceeds $10 \mu \mathrm{g} / \mathrm{g} \mathrm{d.w}$. only during some episodes in the Allerød. (Fig. 2). Submerged aquatic macrophytes principally produce low amounts of pollen and mainly use vegetative strategies for reproduction. Consequently, very low concentrations of aquatic pollen have been counted in the sediment samples. However, macrofossil remains of submerged species Potamogeton and Chara have also been found only in low amounts in some samples from the Allerød and early YD (Fig. 3). This gives evidence that submerged aquatic species have been of low abundance and contributed little to sedimentary organic matter in TRZ throughout the studied time interval, with a somewhat higher proportional input during the Allerød and early YD. Low $\delta^{13} \mathrm{C}$ values, which vary between $-33 \%$ and $-28 \%$, also indicate a primary terrestrial origin of mid-chain $n$-alkanes. Submerged macrophytes use ${ }^{13} \mathrm{C}$-enriched bicarbonate as a carbon source, especially when carbon is limited at highly productive stands, leading to $\delta^{13} \mathrm{C}$ values of $n$-alkanes that can reach up to $-12 \%$ (Allen and Spence, 1981; Keeley and Sandquist, 1992; Aichner et al., 2010a, b). Hence, low $\delta^{13} \mathrm{C}$ values for mid-chain compounds as measured in TRZ either indicate (a) low productivity of submerged macrophytes and/or (b) a relatively high proportional contribution of terrestrial sources to $n \mathrm{C}_{23}$ and $n \mathrm{C}_{25}$. We conclude that these mid-chain compounds comprise a mixture of aquatic and terrestrial sources, especially during the YD and Holocene.

\section{Long-chain $n$-alkanes $\left(n \mathrm{C}_{27}, n \mathrm{C}_{29}, n \mathrm{C}_{31}\right)$}

To further elucidate plant sources of $n$-alkanes in the sediments of TRZ we compared our organic geochemical data to pollen and macrofossil spectra (Fig. 3; low-resolution pollen data from Wulf et al., 2013; decadal pollen-macrofossil data across the Allerød-YD transition from Słowinski et al., 2017; unpublished low-resolution macrofossil data from 12400 $10000 \mathrm{yr}$ BP). Based on these data, the YD was characterized by relatively low amounts of tree and shrub pollen, except for Juniperus, which expands after the YD onset, and enhanced proportional input from herbaceous plants (Poaceae, Cyperaceae, Artemisia, Chenopodiaceae). The arboreal communities during the Allerød and Holocene were dominated by $\mathrm{Pi}$ nus. Relatively high amounts and percentages of pollen and macrofossils derived from Betula sp. were mainly observed in samples from the YD to Holocene transition and also in samples from the early Allerød (Figs. 3 and 4).

From the aliphatic compounds in TRZ, the $n \mathrm{C}_{27}$ alkane shows the largest variability in concentration, which ranges from $<10 \mu \mathrm{g} / \mathrm{g} \mathrm{d}$.w. during the YD up to $>100 \mu \mathrm{g} / \mathrm{g} \mathrm{d}$.w. during the Allerød. This seems to reflect the trend of a contribution of arboreal pollen, specifically from Betula, to the lake sediments (Figs. 3 and 7). Leaf waxes of the gymnosperm tree species Pinus sylvestris have been shown to often contain high relative abundances of $n \mathrm{C}_{27}$ alkanes, but absolute concentrations are in most cases very low (Maffei et al., 2004; Ali et al., 2005; Dove and Mayes, 2005; Diefendorf et al., 2011; Bush and McInerney, 2013). It is therefore likely that Pinus does not contribute significant amounts of $n$-alkanes to the sedimentary archive of TRZ. On the other hand, Betula sp. as the second most abundant tree genera in the lake catchment could have been a major contributor to the sedimentary $n \mathrm{C}_{27}$ pool (Schwark et al., 2002; Diefendorf et al., 2011) and likely biosynthesizes higher absolute amounts compared to Pinus. Comparing palynological abundances and $n \mathrm{C}_{27}$ concentration data supports this idea. The high concentrations of $n \mathrm{C}_{27}$ alkanes during the early Allerød, between ca. 13250 and $13100 \mathrm{yr} \mathrm{BP}$, coincide with an interval characterized by a dominance of Betula over Pinus (Wulf et al., 2013). Further, the increasing concentrations of $n \mathrm{C}_{27}$ between ca. 11700 and $11500 \mathrm{yr} \mathrm{BP}$ were in phase with Betula expansion at the YD-Holocene transition (Fig. 3). Finally, the expansion of Pinus after the onset of the Holocene was not reflected in increasing $n \mathrm{C}_{27}$ concentrations; rather, a decrease in $n$-alkane concentrations was observed. This decrease could be explained by a synchronous decrease in absolute and relative Betula abundances. Based on the covariation of $n \mathrm{C}_{27}$ concentrations and palynological data we consider Betula sp. as a dominant contributor to this compound, while Pinus sylvestris appears to be a less relevant source.

Another gymnosperm shrub species, Juniperus communis, was expanding during the early YD, peaking between ca. 12300 and $12500 \mathrm{yr}$ BP, before gradually declining (Fig. 3; Wulf et al., 2013; Słowinski et al., 2017). Reported $n$-alkane concentrations for this species ranged from very low (Maffei et al., 2004) to high (Mayes et al., 1994). In the study of Diefendorf et al. (2011), Juniperus osteosperma was the only analyzed gymnosperm that showed intermediate concentrations of $n$-alkanes. All these studies reported that $J u$ niperus sp. biosynthesizes relatively long chain lengths, in the range $\mathrm{C}_{31}-\mathrm{C}_{35}$, a pattern which has also been observed in plant samples from Lake Steisslingen (southern Germany; Schwark et al., 2002). This suggests that Juniperus sp. could be a significant contributor to $n \mathrm{C}_{31}$ also in the TRZ sediments, especially during the early YD. During phases of high $n \mathrm{C}_{31}$ abundance in the Allerød and Holocene other contributors must have been predominant.

Herbaceous plants could theoretically contribute to all measured $n$-alkanes, but have often been associated with a 


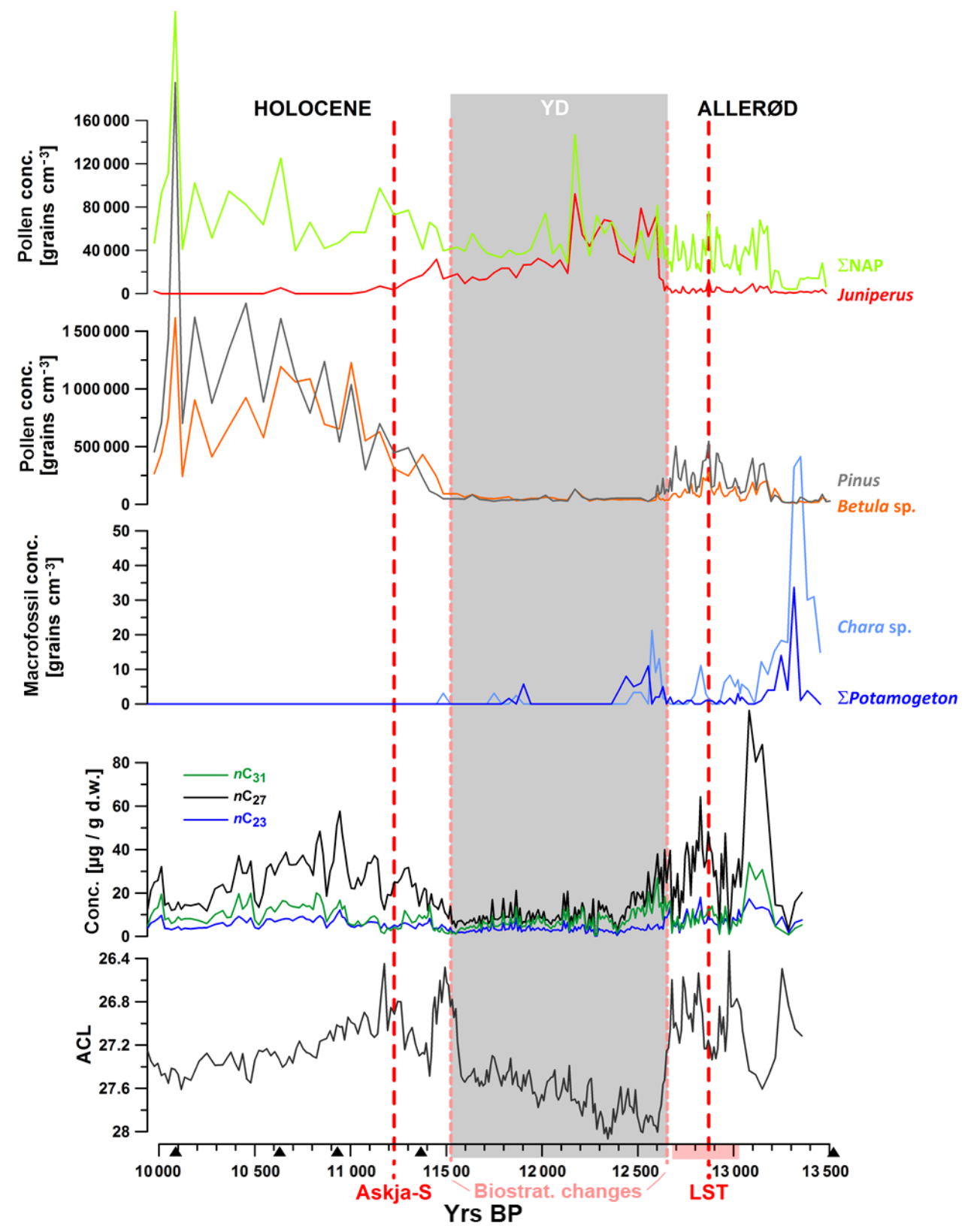

Figure 3. $n$-Alkane concentrations and average chain lengths (ACLs) during the studied interval in comparison to pollen and macrofossil counts (Wulf et al., 2013; Słowinski et al., 2017; unpublished macrofossil data from 10 000-12400 yr BP). NAP: non-arboreal pollen. Grey shaded interval: YD according to pollen cluster.

dominance of longer $n$-alkane chain lengths (e.g., Maffei, 1994, 1996a, b; Zhang et al., 2004; Rommerskirchen et al., 2006). In TRZ, grasses and other herb pollen showed varying concentrations, with a tendency of higher amounts during the YD. Their proportional contribution significantly increased or decreased at the YD onset or termination, which was enhanced by the strong decline of tree pollen during the cold interval. We assume that these types of plants could indeed be strong contributors to the longer chain lengths, i.e., $n \mathrm{C}_{29}$ and $n \mathrm{C}_{31}$, specifically during the $\mathrm{YD}$ when concentrations of those compounds approach values of the dominating $n \mathrm{C}_{27}$ alkane. A proportional contribution from trees cannot be fully excluded, especially during the abovementioned phase of Juniperus expansion (early YD) as well as during parts of the early Holocene and Allerød when Betula was dominating.

Considering emergent aquatic and telmatic species, macrofossils were counted for species such as Typha lati- 


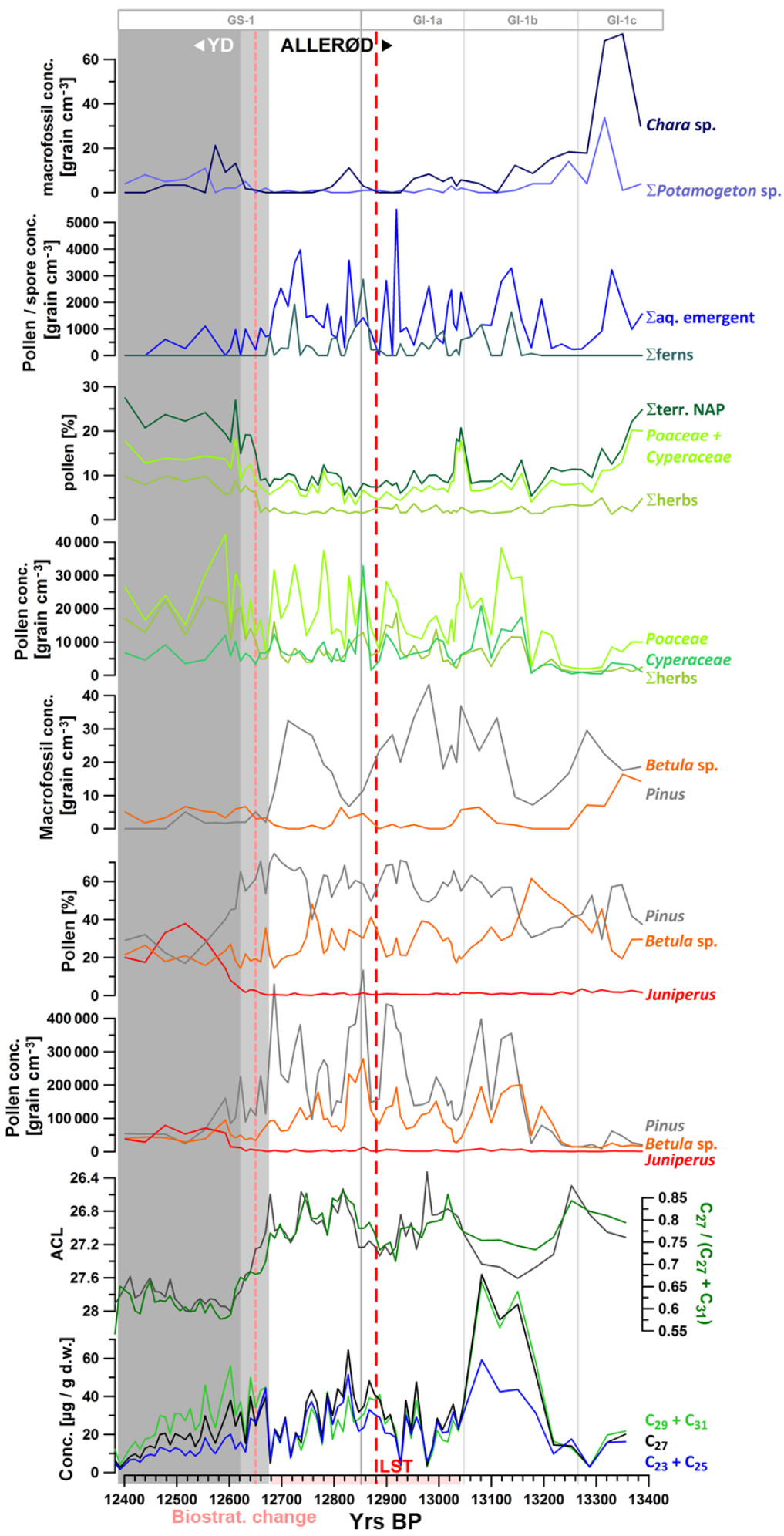

Figure 4. High-resolution palynological data from the Allerød and transition into the YD in comparison to concentration of $n$-alkanes, ACL, and the $\mathrm{C}_{27} /\left(\mathrm{C}_{27}+\mathrm{C}_{31}\right) n$-alkane ratio. The light grey shaded period indicates the transition from the Allerød to the YD (12680$12620 \mathrm{yr} \mathrm{BP}$ ) as defined by Słowinski et al. (2017), while the dark grey shaded interval marks the YD. NGRIP ice core stratification according to Rasmussen et al. (2014). $\Sigma$ herbs: NAP without Poaceae and Cyperaceae. 


\begin{tabular}{|c|c|c|c|c|c|c|c|c|c|}
\hline & c C23 & c C25 & c C27 & c C29 & c C31 & $\Sigma$ all & $\Sigma 2325$ & $\Sigma 2931$ & $\Sigma 272931$ \\
\hline c Pinus sylvestris & 0.37 & 0.49 & 0.43 & 0.34 & 0.27 & 0.41 & 0.46 & 0.32 & 0.38 \\
\hline c Salix & 0.24 & 0.27 & 0.46 & 0.53 & 0.60 & 0.47 & 0.26 & 0.56 & 0.52 \\
\hline c Betula & 0.37 & 0.38 & 0.39 & 0.30 & 0.19 & 0.35 & 0.39 & 0.27 & 0.33 \\
\hline c Hippuris rhamn. & 0.34 & 0.24 & 0.35 & 0.39 & 0.32 & 0.35 & 0.27 & 0.37 & 0.37 \\
\hline c Juniperus & -0.47 & -0.40 & -0.27 & -0.16 & 0.05 & -0.24 & -0.42 & -0.09 & -0.18 \\
\hline c $\Sigma$ AP & 0.34 & 0.45 & 0.42 & 0.34 & 0.28 & 0.40 & 0.42 & 0.32 & 0.38 \\
\hline c Calluna vulgaris & 0.14 & 0.15 & 0.06 & -0.01 & -0.04 & 0.05 & 0.15 & -0.02 & 0.02 \\
\hline c Ericaceae & -0.26 & -0.21 & -0.21 & -0.22 & -0.07 & -0.20 & -0.23 & -0.17 & -0.19 \\
\hline c Helianthenum & -0.45 & -0.41 & -0.32 & -0.28 & -0.19 & -0.33 & -0.43 & -0.25 & -0.29 \\
\hline c Dryas octopetala & 0.21 & 0.10 & 0.18 & 0.23 & 0.18 & 0.19 & 0.13 & 0.21 & 0.20 \\
\hline c Ranunculus & 0.05 & 0.01 & 0.00 & -0.04 & -0.06 & -0.01 & 0.02 & -0.05 & -0.03 \\
\hline c Rumex & -0.17 & -0.18 & 0.00 & 0.07 & 0.19 & 0.00 & -0.18 & 0.12 & 0.06 \\
\hline c Filipendula & 0.16 & 0.32 & 0.24 & 0.15 & 0.11 & 0.22 & 0.27 & 0.14 & 0.19 \\
\hline c Thalictrum & 0.32 & 0.40 & 0.46 & 0.41 & 0.40 & 0.44 & 0.38 & 0.41 & 0.44 \\
\hline c Artemisia & -0.51 & -0.38 & -0.27 & -0.17 & 0.11 & -0.24 & -0.43 & -0.07 & -0.17 \\
\hline c Chenopodiaceae & -0.44 & -0.30 & -0.27 & -0.22 & 0.01 & -0.24 & -0.35 & -0.14 & -0.21 \\
\hline c Poaceae & -0.04 & 0.06 & 0.15 & 0.20 & 0.32 & 0.17 & 0.03 & 0.25 & 0.20 \\
\hline c Cyperaceae & 0.23 & 0.32 & 0.39 & 0.37 & 0.36 & 0.37 & 0.30 & 0.37 & 0.39 \\
\hline c $\Sigma$ terr. NAP & -0.12 & 0.01 & 0.14 & 0.19 & 0.35 & 0.15 & -0.02 & 0.25 & 0.19 \\
\hline c Typha latifolia & -0.03 & -0.01 & -0.07 & -0.09 & -0.13 & -0.07 & -0.02 & -0.10 & -0.09 \\
\hline c Equisetum & 0.26 & 0.23 & 0.17 & 0.13 & 0.01 & 0.16 & 0.24 & 0.09 & 0.13 \\
\hline c Filicales monolete & 0.34 & 0.41 & 0.39 & 0.31 & 0.22 & 0.36 & 0.39 & 0.28 & 0.34 \\
\hline c Botryococcus & 0.33 & 0.49 & 0.47 & 0.42 & 0.41 & 0.46 & 0.45 & 0.42 & 0.45 \\
\hline c Pediastrum & 0.37 & 0.18 & 0.28 & 0.28 & 0.14 & 0.26 & 0.24 & 0.23 & 0.26 \\
\hline
\end{tabular}

Figure 5. Heat map table illustrating Pearson correlation coefficients between concentrations of pollen and $n$-alkanes at the Allerød-YD transition (1230-1271 cm). Data have been $z$-transformed before correlation. Bold black numbers: $p<0.01$. Black numbers: $p<0.05$. Positive correlations in green and negative correlations in red. AP: arboreal pollen. NAP: terrestrial non-arboreal pollen.

folium and Sparganium as well as multiple species of ferns (Fig. 4). Those species might have contributed to the pool of long-chain $n$-alkanes (Ficken et al., 2000), at least during the Allerød and possibly also during the Holocene. After the YD onset, those species widely disappeared from the littoral due to their low tolerance for cool summer temperatures (Fig. 4; Słowinski, et al., 2017).

\section{Statistical correlation across the Allerød-YD transition}

To analyze possible correlations between occurrences of alkanes with vegetation more in detail, we compared $n$ alkane concentrations throughout the Allerød and transition into the YD (ca. 13 350-12400 yr BP) with high-resolution pollen data from the same interval (Figs. 4 and 5). For the latter, data published in Słowinski et al. (2017; 1230-1262 cm) have been complemented by further unpublished data extending further into the Allerød $(1262-1271 \mathrm{~cm})$. Macrofossils have been excluded from this survey (a) due to lower sampling resolution (1 vs. $0.5 \mathrm{~cm}$ for organic geochemical proxies) compared to pollen and organic geochemical data and (b) as macrofossil samples were not taken from the same core.
We found that AP counts as well as some herbaceous plants and ferns showed a significant positive correlation with concentrations of $\mathrm{C}_{25}, \mathrm{C}_{27}$, and $\mathrm{C}_{29} n$-alkanes. In contrast, $n \mathrm{C}_{31}$ concentrations showed a significant correlation with NAP counts, but also with Salix. Significant correlations are also found between $n$-alkane concentrations and algae (Botryococcus, Pediastrum) since the latter have been found in relatively high concentrations during the Allerød. Since Botryococcus does not produce $n$-alkanes (Lichtfouse et al., 1994), this could well be considered as an autocorrelation.

It has to be noted that concentrations of $n$-alkane homologues strongly correlated with one other (Table S3 in the Supplement). This autocorrelation is due to the fact that basically all $n$-alkanes showed the same rough trend with high concentrations during the Allerød and low concentrations during the YD. Autocorrelations could also be found within pollen data; e.g., Pinus counts significantly correlated with Betula $(R=0.79 ; p<0.01$; Table S4 in the Supplement). Hence, significant correlation does not necessarily indicate origin of $n$-alkanes but could be due to intercorrelations between concentrations of source organisms, which is specifically relevant for negative correlations. Principally, 
the correlation coefficients reflect the major trends of pollen counts and $n$-alkane concentrations throughout the AllerødYD transition. Significant positive correlations indicated that the pollen counts follow the rough trend of $n$-alkanes, i.e., high concentrations during the Allerød, low concentrations during the YD. In contrast, significant negative correlations suggested opposite trends, as relevant for Juniperus and some herbs (Artemisia, Chenopodiaceae, Helianthemum)

We conclude that compounds can be attributed to arboreal and non-arboreal sources. Comparison with pollen data suggest that the abundances of Betula and Juniperus in the catchment have had a strong impact on $n$-alkane concentrations and the composition of $n$-alkanes in TRZ sediments. Decreasing concentrations of mid-chain compounds, which are often interpreted as of aquatic origin, are here rather a mixture of aquatic and terrestrial sources, with high proportional input of the latter during certain time periods (see above).

\section{Leads and lags between $n$-alkanes and pollen}

Potential pre-aging of leaf waxes, i.e., residence time in soils before being deposited in sediments, has been a recent matter of debate. Some studies have shown that significant lag times occur before compounds are deposited in sediments, mainly due to long residence time in soils and transport via rivers as well as mixing processes (Eglinton et al., 1997; Uchikawa et al., 2008; Kusch et al., 2010). This is specifically the case for marine sediments but has recently also been shown for lacustrine systems by Douglas et al. (2014). Those authors quantified pre-aging of plant waxes from several hundreds to thousands of years in a warm and humid environment, in which transport times are expected to be low due to high rainfall and runoff. In contrast, Lane et al. (2016) inferred very short lag times for another tropical lake characterized by a small catchment area.

In TRZ we do not observe significant offsets between pollen and $n$-alkane signals neither at the YD onset nor during the termination (Figs. 3, 4, and 7). Especially the data at the YD onset show the most pronounced change in integrative $n$-alkane proxies between 12680 and $12620 \mathrm{kyr} \mathrm{BP}$. This is precisely the time interval defined by Słowinski et al. (2017) as the transition phase between the Allerød and the YD (Fig. 4) based on decadally resolved pollen data. We conclude that leaf waxes experience very short transit times (i.e., subdecadal) before being deposited to the sediments in this small catchment system. We suggest that the major transport pathway of leaf waxes into the sedimentary record in this temperate system is due to direct litterfall into the lake during autumn, when trees shed their leaves.

\subsection{Potential of $n$-alkane ratios as paleoecological proxies in TRZ}

Downcore changes in proxies based on proportional contribution of specific $n$-alkanes (e.g., $P_{\text {aq }}$, ACL, $n$-alkane ra- tios such as $n \mathrm{C}_{27} / n \mathrm{C}_{31}$ ) have frequently been applied to decipher paleoecological changes. Nevertheless, due to the abovementioned constraints, the applicability of alkane ratios as source indicators has been questioned, acknowledging that a uniform interpretation of proxies such as ACL is not possible (Rao et al., 2011; Bush and McInerney, 2013; Hoffmann et al., 2013). Our data illustrate that vegetation changes co-occurred with compositional changes in sedimentary $n$ alkanes and we argue that if constraints from other proxy data can be made, specific additional information can be derived from such proxies.

To test their applicability in our study area we correlated standard $n$-alkane ratios with pollen percentages during the interval 13 350-12 $400 \mathrm{yr}$ BP (Allerød-YD transition) (Fig. 6), when the strongest changes occurred. Positive correlations were found between $n$-alkane ratios and arboreal pollen from Pinus and Betula. The same ratios showed negative correlations to non-arboreal pollen (NAP) and arboreal pollen (AP) from Juniperus and Salix. The highest positive PCC was given by the ratio $n \mathrm{C}_{27} /\left(n \mathrm{C}_{27}+n \mathrm{C}_{31}\right)$ versus percentage of $\Sigma$ AP excluding Juniperus and Salix $(R=0.81$, $p<0.001$; Fig. 6). The same ratio also delivered the most negative coefficients for correlations versus relative amounts of NAP, grasses, herbs, Juniperus, and Salix. Slightly lower correlations were found for the ratio $\left(n \mathrm{C}_{27}+n \mathrm{C}_{29}\right) /\left(n \mathrm{C}_{27}+\right.$ $n \mathrm{C}_{29}+n \mathrm{C}_{31}$ ), but principally all the analyzed ratios were good indicators to express changes in vegetation. Interestingly, the ratio $n \mathrm{C}_{29} /\left(n \mathrm{C}_{29}+n \mathrm{C}_{31}\right)$ strongly correlated with percentages of Betula $(R=0.80, p<0.001$; Fig. 6$)$, which is considered as a major $n \mathrm{C}_{27}$ producer. Given the discussion of sources of the compounds above, this could indicate that this proxy is useful to assess the proportional contribution of Betula to long-chain $n$-alkanes $\mathrm{C}_{29}$ and $\mathrm{C}_{31}$.

Similar to pollen vs. $n$-alkane concentrations, autocorrelations need to be considered when interpreting $n$-alkane-based proxies. For instance, if the aquatic contribution to the sediment is low as in TRZ, then the $P_{\text {aq }}$ must not be interpreted as a measure for aquatic influx but instead as an alternative expression for ACL, which explains the similarity of both curves (Fig. 2).

Although an exact assignment to sources was difficult, significant changes in $n$-alkane ratios mirrored shifts of pollen percentages throughout the YD onset. Therefore, we consider alkane ratios to be a good indicator for major ecological changes in the lake catchment. We suggest that a shift towards longer chain lengths at the YD onset (reflected by higher ACL and by long-chain alkane ratios) was indicative of a shift of a more tree-dominated catchment (Pinus-Betula communities, Wulf et al., 2013) to a higher abundance of herbaceous plants, complemented by shrubs Juniperus and Salix. 


\begin{tabular}{|c|c|c|c|c|c|c|c|}
\hline & $P_{a q}$ & $\begin{array}{c}\mathrm{C} 27 / \\
(\mathrm{C} 27+\mathrm{C} 31)\end{array}$ & $\begin{array}{c}\mathrm{C} 27 / \\
(\mathrm{C} 27+\mathrm{C} 29)\end{array}$ & $\begin{array}{c}\mathrm{C} 27 / \\
(\mathrm{C} 27+\mathrm{C} 29+\mathrm{C} 31)\end{array}$ & $\begin{array}{c}\mathrm{C29} / \\
(\mathrm{C} 29+\mathrm{C} 31)\end{array}$ & $\begin{array}{c}(C 27+C 29) / \\
(C 27+C 29+C 31)\end{array}$ & $\mathrm{ACL}$ \\
\hline$\Sigma$ AP & 0.69 & 0.78 & 0.65 & 0.76 & 0.59 & 0.74 & -0.70 \\
\hline$\Sigma$ AP wo. Juniperus & 0.68 & 0.80 & 0.62 & 0.75 & 0.63 & 0.77 & -0.72 \\
\hline I AP wo. Junip. \& salix & 0.69 & 0.81 & 0.62 & 0.76 & 0.63 & 0.78 & -0.72 \\
\hline Betula & 0.37 & 0.56 & 0.08 & 0.32 & 0.69 & 0.60 & -0.50 \\
\hline Pinus sylvestris & 0.51 & 0.50 & 0.64 & 0.62 & 0.22 & 0.43 & -0.45 \\
\hline Juniperus & -0.64 & -0.76 & -0.56 & -0.70 & -0.61 & -0.74 & 0.68 \\
\hline Salix & -0.71 & -0.65 & -0.64 & -0.70 & -0.43 & -0.60 & 0.68 \\
\hline$\Sigma$ terr. NAP & -0.70 & -0.81 & -0.65 & -0.77 & -0.62 & -0.77 & 0.73 \\
\hline Poaceae + cyperaceae & -0.60 & -0.68 & -0.56 & -0.67 & -0.51 & -0.65 & 0.61 \\
\hline Poaceae & -0.57 & -0.65 & -0.57 & -0.66 & -0.47 & -0.62 & 0.59 \\
\hline Cyperaceae & -0.44 & -0.48 & -0.29 & -0.41 & -0.45 & -0.48 & 0.45 \\
\hline$\Sigma$ herbs & -0.72 & -0.85 & -0.65 & -0.80 & -0.68 & -0.82 & 0.76 \\
\hline Artemisia & -0.70 & -0.85 & -0.62 & -0.78 & -0.70 & -0.83 & 0.75 \\
\hline Chenopodiaceae & -0.53 & -0.66 & -0.45 & -0.59 & -0.56 & -0.65 & 0.57 \\
\hline$\Sigma$ ferns & 0.23 & 0.38 & -0.04 & 0.15 & 0.52 & 0.43 & -0.31 \\
\hline$\Sigma$ aq subm $\&$ float & -0.21 & -0.23 & -0.27 & -0.27 & -0.11 & -0.20 & 0.21 \\
\hline$\Sigma$ aq emergent & 0.05 & 0.12 & -0.07 & 0.01 & 0.19 & 0.15 & -0.08 \\
\hline$\Sigma$ algae & 0.01 & 0.20 & -0.35 & -0.12 & 0.48 & 0.28 & -0.13 \\
\hline Sphagnum & 0.46 & 0.38 & 0.57 & 0.53 & 0.13 & 0.32 & -0.42 \\
\hline
\end{tabular}

Figure 6. Heat map table showing Pearson correlation coefficients between pollen percentages and $n$-alkane ratios. Data have been $z$ transformed before correlation. Bold black numbers: $p<0.01$. Black numbers: $p<0.05$. Positive correlations in green and negative correlations in red. Intercorrelation between relative abundances of pollen and $n$-alkane ratios are in Tables S3 and S5 in the Supplement. AP: arboreal pollen. Terr. NAP: terrestrial non-arboreal pollen. $\Sigma$ other herbs: NAP without Poaceae and Cyperaceae.

\subsection{Paleoecological and climatic context}

During the Allerød, i.e., between 13360 and $12680 \mathrm{yrBP}$, an average ACL of ca. 26.9 reflects the vegetation communities consisting of Pinus and Betula forests (Fig. 7). Shifts towards longer chain lengths $(>27.4)$ occurred between ca. $13220-13050$ and $12970-12850 \mathrm{yr}$ BP. Climatic variations during the Allerød were detected in numerous paleoclimatic records. The most recent chronology from NGRIP ice cores dated the Greenland interstadial cooling phase $1 \mathrm{~b}$ (GI-1b) to $13261 \pm 149$ to $13049 \pm 143 \mathrm{yr} \mathrm{BP}$ (Rasmussen et al., 2014; Fig. 5). This episode has been suggested to be equivalent to the "Gerzensee oscillation", which has been observed in lake sediment records (von Grafenstein et al., 1999, 2000). In our record the ACL reversal between ca. 13220 and $13050 \mathrm{yr} \mathrm{BP}$ could probably be considered as a response of vegetation in the TRZ catchment to this cold oscillation, but the synchronicity of events could not be fully confirmed due to larger uncertainties of the age model in the non-varved section of the record. Another minor and short-term cooling reversal ca. 40 years before the onset of the YD, at around $12720 \mathrm{yr}$ BP, has recently been proposed for MFM (Engels et al., 2016) but was not clearly recorded by $n$-alkane ratios in TRZ because of the insufficient time resolution of our data.

The sharpest and most pronounced decrease in ACL was measured between 12680 and $12600 \mathrm{yr}$ BP. This was synchronous with the transition phase of major vegetation changes as inferred from palynological data between 12680 and $12620 \mathrm{yr}$ BP (Słowinski et al., 2017). No pronounced lag time for organic biomarkers, for instance due to prolonged residence time in soils or transport from the catchment to the lake, was observed. Given the precise age control in this varved and tephrochronologically anchored section of the record, the rapid vegetation change marking the YD onset appeared to be delayed by ca. 170 years compared to the onset of cooling as inferred from Greenland ice cores (GS-1 onset $12846 \pm 138$ yr BP; Rasmussen et al., 2014), similarly as suggested for more westerly locations such as MFM (Rach et al., 2014). While the combined absolute dating uncertainty of both records (NGRIP and MFM) exceeds this delay, the relative age uncertainty in this section is much lower, evidenced by the common occurrence of the Vedde Ash isochron in MFM and NGRIP with a relative age difference of only 19 years (Lane et al., 2013; Rach et al., 2014) when based on their independent age models. The TRZ record can be linked 

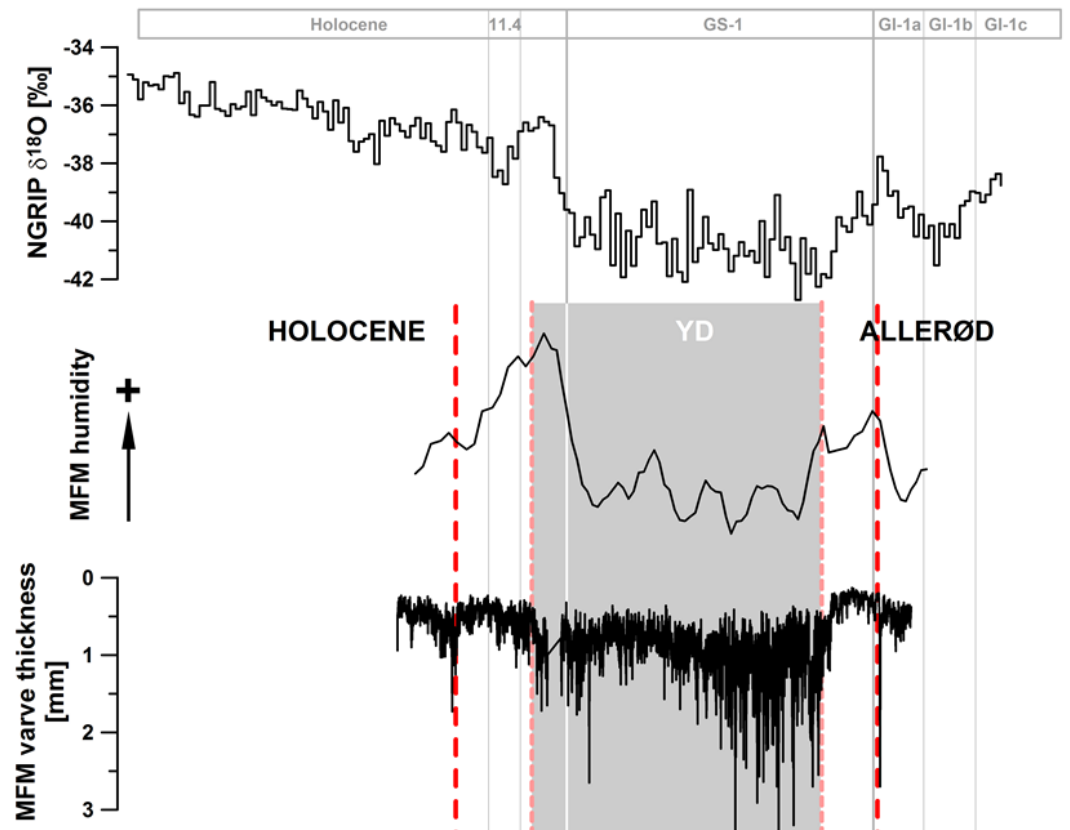

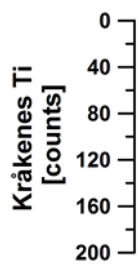
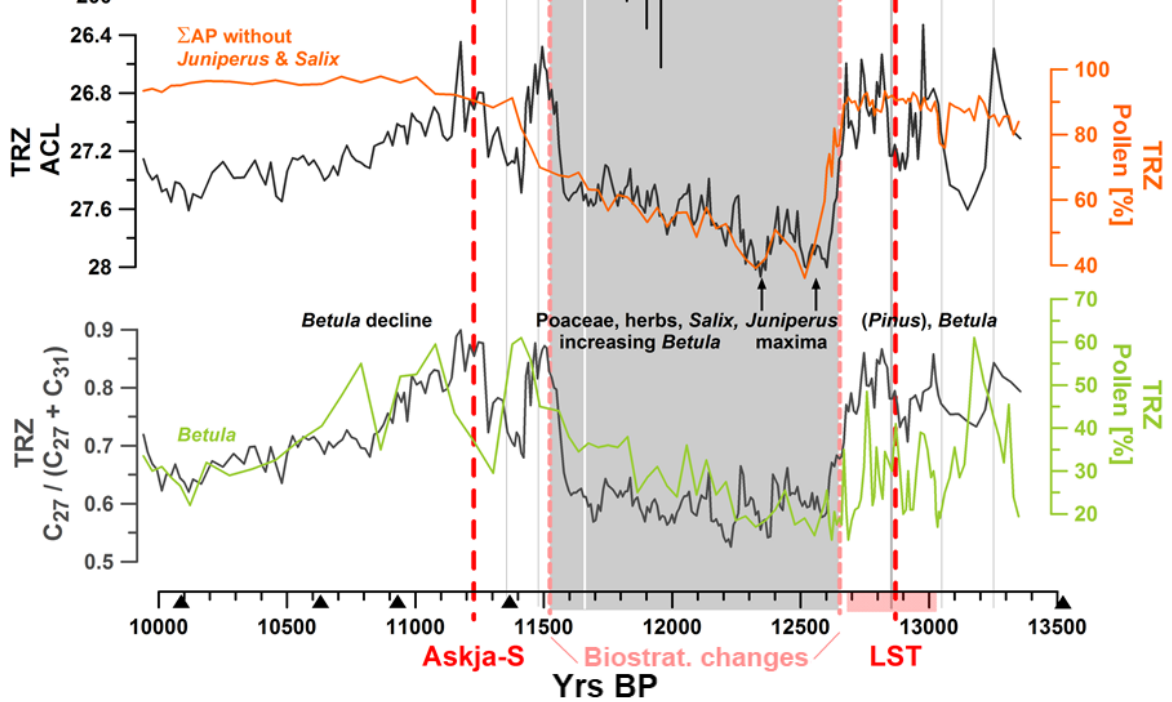

Figure 7. Data comparison to MFM (Brauer et al., 1999b; Rach et al., 2014), Lake Kråkenes (Bakke et al., 2009), and NGRIP (Rasmussen et al., 2014).

to NGRIP indirectly through MFM, with which it shares the LST at $12880 \mathrm{yr}$ BP (Wulf et al., 2013; Brauer et al., 1999a, b, 2011), resulting in similarly low relative age uncertainties, at least in the varved core section.

Within the YD cold interval, the ACL was showing a gradual trend towards lower values. While some potential con- tributors to longer chain lengths such as Poaceae, Cyperaceae, and other herbaceous plants showed relatively constant pollen counts during the YD, some others such as $J u$ niperus were more abundant during the first half of the YD (Wulf et al., 2013; Figs. 3 and 7). This is in agreement with the principal trend of $\delta^{18} \mathrm{O}$ values and $\mathrm{Ca}^{2+}$ concentrations 
in Greenland ice cores, which indicated the coldest and driest conditions in the earlier phase of the YD, followed by a gradual and slight warming (Rasmussen et al., 2014). A similar pattern was also detected within proxy data from other European lakes, for example MFM (varve thickness, elemental composition, and $\delta D$ values; Brauer et al., 1999a, b; Rach et al., 2014), Ammersee ( $\delta^{18} \mathrm{O}$; von Grafenstein et al., 2003), paleolake Rehwiese (varve thickness; Neugebauer et al., 2012), and Lake Kråkenes (elemental composition; Lane et al., 2013; Fig. 7). Recently this bipartitioning of the YD was also observed in Lake Suigetsu (Schlolaut et al., 2017). Explanations for this phenomenon have been related to a restrengthening of the AMOC at ca. $12300 \mathrm{yr}$ BP. Its slowdown and the consequent southward shifting of the polar front are considered as major triggers for the YD in Europe (McManus et al., 2004; Bakke et al., 2009; Elmore and Wright, 2011). The gradual strengthening of the AMOC pushed the polar front back to the north, which is the reason that the partially rapid climatic responses occurred earlier at more southern (ca. $12240 \mathrm{yr}$ BP at MFM) compared to more northern locations (ca. 12140 yr BP at Lake Kråkenes) (Brauer et al., 2008; Lane et al., 2013). At TRZ, ACL, as an integrative proxy, showed shifts at ca. 12300-12280 and 12200$12190 \mathrm{yr}$ BP, but changes were gradual and did not allow for a distinct identification of the timing of this climatic change. An explanation for this could be the continental setting of our study area, which showed weaker climatic responses compared to locations with stronger Atlantic influence (Słowinski et al., 2017).

The succession of $n$-alkane abundances between ca. 11540 and $11200 \mathrm{yr}$ BP reflects the gradual expansion of vegetation around the YD-Holocene transition (defined by means of biostratigraphy at $11515 \pm 35 \mathrm{yr} \mathrm{BP}$; Table 1) and during the early Holocene. An increase in $n \mathrm{C}_{27}$ concentrations starting around $11540 \mathrm{yr} \mathrm{BP}$, while $n \mathrm{C}_{31}$ reached the lowest concentrations within the studied interval, was possibly caused by expansion of Betula and triggered a sharp decrease in ACL between 11580 and $11490 \mathrm{yr} \mathrm{BP}$. This shift occurred ca. 70-80 years earlier compared to the defined onset of the Holocene in Greenland at $11654 \pm 4 \mathrm{yr}$ BP based on oxygen isotopes in the NGRIP ice core (Rasmussen et al., 2014). Due to age uncertainties between 35 and 90 years within the respective section of the TRZ record, ultimate quantification of the lag was not possible in this case.

A sudden increase in $n \mathrm{C}_{29}$ and $n \mathrm{C}_{31}$ concentrations at ca. $11430 \mathrm{yr}$ BP (Fig. 2), i.e., 90 years after the start of increasing $n \mathrm{C} 27$ concentration, was associated with a ca. 180-year reversal of ACL and $n$-alkane ratios, whose start was in phase with a cold period in Greenland referred to as the $11.4 \mathrm{kyr}$ event (Rasmussen et al., 2014). In contrast to the YD, which was characterized by low concentrations of $n$-alkanes, the increasing ACL at $11.5 \mathrm{kyr} \mathrm{BP}$ was triggered by an increase in concentrations of long-chain compounds. It is likely that the rapid ecological developments in the lake catchment in the course of warming, such as expansion of forest vegeta- tion and development of soils, were the main drivers behind the observed shift and not a response to a cooling within the catchment.

Cold reversals during the early Holocene are mostly referred to as pre-boreal oscillations (PBOs) and have been inferred from different proxies in many European lakes. The exact timing and possible synchronicity of these oscillations is still a matter of debate and PBOs are generally difficult to detect in lake sediments (e.g., Björk et al., 1997; Bos et al., 2007). Based on sedimentary analysis of a lake in southern Sweden, Wohlfahrt et al. (2006) suggested a PBO could be stratigraphically located between tephra layers Hässeldalen and Askja-S, which have been dated to $11380 \pm 216$ and $11228 \pm 226$, respectively (Ott et al., 2016). The fact that the decrease in ACL in the TRZ sediment core was observed ca. $10 \mathrm{~cm}$ below the Askja-S layer is evidence against a connection to the oscillation, at least according to the stratigraphic boundaries suggested by Wohlfahrt et al. (2006).

The upper $31 \mathrm{~cm}$ of the studied core interval covered the early Holocene from ca. 10970 to $9940 \mathrm{yr} \mathrm{BP}$ at relatively low resolution due to lower sedimentation rates and increased sample size. This episode was characterized by a gradual change in $n$-alkane ratios, e.g., an increase in ACL, indicating the gradual establishment of Holocene vegetation in the lake catchment due to further gradual warming. Specifically after ca. $10600 \mathrm{yr} \mathrm{BP}$, a decrease in mainly $n \mathrm{C}_{27}$ alkane concentrations probably indicated a decline of Betula and further expansion of Pinus sylvestris as dominating species (Wulf et al., 2013).

\section{Conclusion}

The YD cold interval was characterized by relatively low concentrations of $n$-alkanes and pronounced changes in their relative abundances, which resulted in significant changes in $n$-alkane-based proxies. The shift towards higher ACL at the Allerød-YD transition between 12680 and $12600 \mathrm{yr}$ BP was in phase with a lower contribution of tree pollen (Pinus and Betula) to the sediments and a subsequently higher abundance of pollen derived from herbaceous plants (Poaceae, Cyperaceae, and Artemisia), as well as shrubs (Juniperus and Salix). These major vegetation changes occurred ca. 170 years after the start of $\delta^{18} \mathrm{O}$ decrease (GS-1 onset $12846 \pm 138 \mathrm{yr}$ BP) in Greenland ice cores. The YDHolocene transition was characterized by a gradual increase in $n \mathrm{C}_{27}$ concentrations starting at ca. $11540-11530 \mathrm{yr} \mathrm{BP}$, most likely induced by an expansion of Betula and a sharp increase in $n \mathrm{C}_{29}$ and $n \mathrm{C}_{31}$ concentrations ca. 90 years later. Due to larger age uncertainties in the nonlaminated section of the core, these ecological changes were more difficult to place into context with the major warming in Greenland (11 $654 \pm 4$ yr BP).

Short-term reversals of ACL and $n$-alkane ratios during the Allerød could possibly be linked to GI-1b, while a sim- 
ilar pattern during the early Holocene was more likely triggered by rapid ecological responses in the course of warming. These results show that there is no standard interpretation of changing proxy values. Instead, responses such as changes in ACL need to be discussed under careful evaluation of the parameters leading to the observed changes. Taking our studied interval, the major identified shifts towards longer chain lengths (i.e., during the Allerød, the YD, between 11430 and $11250 \mathrm{yr} \mathrm{BP}$, and after 11070 years) had different causes because either an increase or decrease in specific compounds triggered the individual response.

We did not observe significant lag times between the response of pollen and $n$-alkane data during periods of abrupt change (i.e., on multidecadal timescales), indicating $n$-alkane residence times in the catchment below our sampling resolution (decades). However, organic geochemical data integrated different information compared to pollen, as there is evidence that Pinus sylvestris, despite being a dominant tree species in the TRZ catchment, has a minor impact on $n$-alkane-based parameters. Overall, this study shows that $\mathrm{ACL}$ and ratios of $n$-alkanes are suitable integrative proxies to track major and abrupt vegetation changes in a local setting, for example in lacustrine environments with relatively small catchments.

Data availability. Data can be accessed in Tables S1 and S2 in the Supplement.

Supplement. The supplement related to this article is available online at: https://doi.org/10.5194/cp-14-1607-2018-supplement.

Author contributions. FO and $\mathrm{AB}$ provided the samples and the age-depth model. BA processed and analyzed the samples in the lab of DS. MS and AMN provided pollen data and unpublished macrofossil data. DS acquired financial support and conceived the project. BA wrote the paper with contributions from all coauthors.

Competing interests. The authors declare that they have no conflict of interest.

Acknowledgements. This study was supported through an ERC Consolidator Grant (STEEPclim, grant agreement no. 647035) to Dirk Sachse, by a grant from the Polish National Science Centre (2015/17/B/ST10/03430) to Michał Słowiński, and a 6-month fellowship from the German Academic Exchange Service (DAAD) to Bernhard Aichner. This study is a contribution to the Virtual Institute of Integrated Climate and Landscape Evolution (ICLEA) of the Helmholtz Association (http://www.iclea.de/, last access: 2 November 2018). We thank Sophie Boven and Michael Poehle for help during sample preparation.
Edited by: Denis-Didier Rousseau

Reviewed by: three anonymous referees

\section{References}

Aichner, B., Herzschuh, U., and Wilkes, H.: Influence of aquatic macrophytes on stable carbon isotope signatures of sedimentary organic matter in lakes on the Tibetan Plateau, Org. Geochem., 41, 706-718, 2010a.

Aichner, B., Herzschuh, U., Wilkes, H., Mischke, S., and Zhang, C.: Biomarker and compound-specific carbon isotope evidence for changing environmental and carbon-limiting conditions at Koucha Lake, Eastern Tibetan Plateau, J. Paleolimnol., 44, 873899, 2010b.

Ali, H. A. M., Mayes, R. W., Hector, B. L., Verma, A. K., and Ørskov, E. R: The possible use of $n$-alkanes, long-chain fatty alcohols and long-chain fatty acids as markers in studies of the botanical composition of the diet of free-ranging herbivores, J. Agric. Sci., 143, 85-95, 2005.

Allen, E. D. and Spence, D. H. N.: The differential ability of aquatic plants to utilize the inorganic carbon supply in fresh water, New Phytol., 87, 269-283, 1981.

Baas, M., Pancost, R., Van Geel, B., and Sinninghe Damste, J. S.: A comparative study of lipids in Sphagnum species, Org. Geochem., 31, 535-541, 2000.

Bakke, J., Lie, O., Heegaard, E., Dokken, T., Haug, G. H., Birks, H. H., Dulski, P., and Nilsen, T.: Rapid oceanic and atmospheric changes during the Younger Dryas cold period, Nat. Geosci., 2, 202-205, 2009.

Björck, S., Rundgren, M., and Funder, S.: The Preboreal oscillation around the Nordic Seas: terrestrial and lacustrine responses, J. Quaternary Sci., 12, 455-465, 1997.

Błaszkiewicz, M., Piotrowski, J. A., Brauer, A., Gierszewski, P., Kordowski, J., Kramkowski, M., Lamparski, P., Lorenz, S., Noryśkiewicz, A. M., Ott, F., Słowiński, M., and Tyszkowski, S.: Climatic and morphological controls on diachronous postglacial lake and river valley evolution in the area of Last Glaciation, northern Poland, Quaternary Sci. Rev., 109, 13-27, 2015.

Bos, J. A. A., Van Geel, B., and Van der Plicht, J., and Bohnke, S. J. P.: Preboreal climate oscillations in Europe: wigglematch dating and synthesis of Dutch high-resolution multi-proxy records, Quaternary Sci. Rev., 26, 1927-1950, 2007.

Brauer, A., Endres, C., Günter, C., Litt, T., Stebich, M., and Negendank, J. F. W.: High resolution sediment and vegetation responses to Younger Dryas climate change in varved lake sediments from Meerfelder Maar, Germany, Quaternary Sci. Rev., 18, 321-329, 1999a.

Brauer, A., Endres, C., and Negendank, J. F. W.: Lateglacial calendar year chronology based on annually laminated sediments from Lake Meerfelder Maar, Germany, Quatern. Int., 61, 17-25, $1999 b$.

Brauer, A., Litt, T., Negendank, J. F. W., and Zolitschka, B.: Lateglacial varve chronology and biostratigraphy of lakes Holzmaar and Meerfelder Maar, Germany, Boreas, 30, 83-88, 2001.

Brauer, A., Haug, G. H., Dulski, P., Sigman, D. M., and Negendank, J. F. W.: An abrupt wind shift in western Europe at the onset of the Younger Dryas cold period, Nat. Geosci., 1, 520-523, 2008.

Bronk Ramsey, C.: Development of the radiocarbon calibration program, Radiocarbon, 43, 355-363, 2001. 
Bronk Ramsey, C.: Deposition models for chronological records, Quaternary Sci. Rev., 27, 42-60, 2008.

Bronk Ramsey, C. and Lee, S.: Recent and planned developments of the program OxCal, Radiocarbon, 55, 720-730, 2013.

Bush, R. T. and McInerney, F. A.: Leaf wax $n$-alkane distributions in and across modern plants: Implications for paleoecology and chemotaxonomy, Geochim. Cosmochim. Ac., 117, 161-179, 2013.

Denton, G. H., Anderson, R. F., Toggweiler, J. R., Edwards, R. L., Schaefer, J. M., and Putnam, A. E.: The Last Glacial Termination, Science, 328, 1652-1656, 2010.

Diefendorf A. F., Freeman K. H., Wing S. L., and Graham H. V.: Production of $n$-alkyl lipids in living plants and implications for the geologic past, Geochim. Cosmochim. Ac., 75, 7472-7485, 2011.

Douglas, P. M. J., Pagani, M., Eglinton, T. I., Brenner, M., Hodell, D. A., Curtis, J. H., Ma, K. F., and Breckenridge, A.: Pre-aged plant waxes in tropical lake sediments and their influence on the chronology of molecular paleoclimate proxy records, Geochim. Cosmochim. Ac., 141, 346-364, 2014.

Dove H. and Mayes, R. W.: Using $n$-alkanes and other plant wax components to estimate intake, digestibility and diet composition of grazing/browsing sheep and goats, Small Ruminant. Res., 59, 123-139, 2005.

Eglinton, G. and Hamilton, R. J.: Leaf epicuticular waxes, Science, 156, 1322-1335, 1967.

Eglinton, T. I., Benitez-Nelson, B., Pearson, A., McNichol, A. P., Bauer, J. E., and Druffel, E. R. M.: Variability in radiocarbon ages of individual organic compounds from marine sediments, Science, 277, 796-799, 1997.

Elmore, A. C. and Wright, J. D.: North Atlantic Deep Water and climate variability during the Younger Dryas cold period, Geology, 39, 107-110, 2011.

Engels, S., Brauer A., Buddelmeijer, N., Martin-Puertas, C., Rach, O., Sachse, D., and Van Geel, B.: Subdecadal-scale vegetation responses to a previously unknown late-Allerød climate fluctuation and Younger Dryas cooling at Lake Meerfelder Maar (Germany), J. Quaternary Sci. 31, 741-752, 2016.

Farquhar, G. D., Ehleringer, J. R., and Hubick, K. T.: Carbon isotope discrimination and photosynthesis, Annu. Rev. Plant Phys., 40, 503-537, 1989.

Feakins, S.: Pollen-corrected leaf wax $D / H$ reconstructions of northeast African hydrological changes during the late Miocene, Palaeogeogr. Palaeocl., 374, 62-71, 2013.

Ficken, K..J., Li, B., Swain, D. L., and Eglinton, G.: An $n$-alkane proxy for the sedimentary input of submerged/floating freshwater aquatic macrophytes, Org. Geochem., 31, 745-749, 2000.

Firbas, F.: Spät- und nacheiszeitliche Waldgeschichte Mitteleuropas nördlich der Alpen. I. Allgemeine Waldgeschichte, Gustav Fischer Verlag, Jena, Germany, 1949.

Gao, L., Hou, J. Z., Toney, J., MacDonald, D., and Huang, Y. S.: Mathematical modeling of the aquatic macrophyte inputs of midchain $n$-alkyl lipids to lake sediments: Implications for interpreting compound specific hydrogen isotopic records, Geochim. Cosmochim. Ac., 75, 3781-3791, 2011.

Garcin, Y., Schefuß, E., Schwab, V. F., Garreta, V., Gleixner, G., Vincens, A., Todou, G., Séné, O., Onana, J.-M., Achoundong, G., and Sachse, D.: Reconstructing C3 and C4 vegetation cover using $n$-alkane carbon isotope ratios in recent lake sediments from
Cameroon, Western Central Africa, Geochim. Cosmochim. Ac., 142, 482-500, 2014.

Gierga, M., Hajdas, I., van Raden, U. J., Gilli, A., Wacker, L., Sturm, M., Bernasconi, S. M., and Smittenberg, R. H.: Longstored soil carbon released by prehistoric land use: evidence from compound-specific radiocarbon analysis on Soppensee lake sediments, Quaternary Sci. Rev., 144, 123-131, 2016.

Goslar, T., Arnold, M., Tisnerat-Laborde, N., Czernik, J., and Wieckowski, K.: Variations of Younger Dryas atmospheric radiocarbon explicable without ocean circulation changes, Nature, 403, 877-880, 2000.

Hanisch, S., Ariztegui, D., and Puttmann, W.: The biomarker record of Lake Albano, central Italy-implications for Holocene aquatic system response to environmental change, Org. Geochem., 34, 1223-1235, 2003.

Heiri, O., Brooks, S. J., Renssen, H., Bedford, A., Hazekamp, M., Ilyashuk, B., Jeffers, E. S., Lang, B., Kirilova, E., Kuiper, S., Millet, L., Samartin, S., Toth, M., Verbruggen, F., Watson, J. E., van Asch, N., Lammertsma, E., Amon, L., Birks, H. H., Birks, J. B., Mortensen, M. F., Hoek, W. Z., Magyari, E., Sobrino, C. M., Seppä, H., Tinner, W., Tonkov, S., Veski, S., and Lotter, A. F.: Validation of climate model-inferred regional temperature change for late-glacial Europe, Nat. Commun., 5, 4914, https://doi.org/10.1038/ncomms5914, 2014.

Hockun, K., Mollenhauer, G., Ho, S. L., Hefter, J., Ohlendorf, C., Zolitschka, B., Mayr, C., Lücke, A., and Schefuß, E.: Using distributions and stable isotopes of $n$-alkanes to disentangle organic matter contributions to sediments of Laguna Potrok Aike, Argentina, Org. Geochem., 102, 110-119, 2016.

Hoffmann, B., Kahmen, A., Cernusak, L. A., Arndt, S. K., and Sachse, D.: Abundance and distribution of leaf wax $n$-alkanes in leaves of Acacia and Eucalyptus trees along a strong humidity gradient in northern Australia, Org. Geochem., 62, 62-67, 2013.

Iversen J.: The development of Denmark's nature since the Last Glacial. Danmarks Geologiske Undersøgelse, Række, 7, 1-126, 1973.

Keeley, J. E. and Sandquist, D. R.: Carbon: freshwater plants, Plant Cell Environ., 15, 1021-1035, 1992.

Kozłowska-Szczęsna, T.: Temperatury powietrza w Polsce w trzydziestoleciu 1951-1980, Zeszyty Instytutu Geografii i Przestrzennego Zagospodarowania, PAN, 18, 5-29, 1993.

Kusch, S., Rethemeyer, J., Schefuß, E., and Mollenhauer, G.: Controls on the age of vascular plant biomarkers in Black Sea sediments, Geochim. Cosmochim. Ac., 74, 7031-7047, 2010.

Lane, C. S., Brauer, A., Blockley, S. P. E., and Dulski, P.: Volcanic ash reveals time-transgressive abrupt climate change during the Younger Dryas, Geology, 41, 1251-1254, 2013.

Lane, C. S., Horn, S. P., Taylor, Z. P., and Kerr, M.: Correlation of bulk sedimentary and compound-specific $\delta^{13} \mathrm{C}$ values indicates minimal pre-aging of $n$-alkanes in a small tropical watershed, Quaternary Sci. Rev., 145, 238-242, 2016.

Lichtfouse, E., Derenne, S., Mariotti, A., and Largeau, C.: Possible algal origin of long chain odd $n$-alkanes in immature sediments as revealed by distributions and carbon isotope ratios, Org. Geochem., 22, 1023-1027, 1994.

Litt, T., Brauer, A., Goslar, T., Merkt, J., Balaga, K., Müller, H., Ralska-Jasiewiczowa, M., Stebich, M., and Negendank, J. F. W.: Correlation and synchronisation of Lateglacial continental sequences in northern central Europe based on annually lami- 
nated lacustrine sediments, Quaternary Sci. Rev., 20, 1233-1249, 2001.

Liu, W. and Huang, Y.: Compound specific $D / H$ ratios and molecular distributions of higher plant leaf waxes as novel paleoenvironmental indicators in the Chinese Loess Plateau, Org. Geochem., 36, 851-860, 2005.

Liu, W., Yang, H., Wang, H., An, Z., Wang, Z., and Leng, Q.: Carbon isotope composition of long chain leaf wax $n$-alkanes in lake sediments: A dual indicator of paleoenvironment in the QinghaiTibet Plateau, Org. Geochem., 83-84, 190-201, 2015.

Maffei, M.: Discriminant analysis of leaf wax alkanes in the Lamiaceae and four other plant families, Biochem. Syst. Ecol. 22, 711-728, 1994

Maffei, M.: Chemotaxonomic significance of leaf wax alkanes in the Graminae, Biochem. Syst. Ecol., 24, 53-64, 1996a.

Maffei, M.: Chemotaxonomic significance of leaf wax n-alkanes in the Umbelliferae, Cruciferae and Leguminosae (Subf. Papilionoideae), Biochem. Syst. Ecol., 24, 531-545, 1996 b.

Maffei, M., Badino, S., and Bossi, S.: Chemotaxonomic significance of leaf wax $n$-alkanes in the Pinales (Coniferales), J. Biol. Res., 1, 3-19, 2004.

Marks, L.: Timing of the Late Vistulian (Weichselian) glacial phases in Poland, Quaternary Sci. Rev. 44, 81-88, 2012.

Mayes, R. W., Beresford, N. A., Lamb, C. S., Barnett, C. L., Howard, B. J., Jones, B.-E. V., Eriksson, O., Hove, K., Pedersen, Ø., and Staines, B. W.: Novel approaches to the estimation of intake and bioavailability of radiocaesium in ruminants grazing forested areas, Sci. Total Environ., 157, 289-230, 1994.

McManus, J. F., Francois, R., Gherardl, J.-M., Kelgwin, L., and Drown-Leger, S.: Collapse and rapid resumption of Atlantic meridional circulation linked to deglacial climate changes, Nature, 428, 834-837, 2004.

Mead, R., Xu, Y., Chong, J., and Jaffé, R.: Sediment and soil organic matter source assessment as revealed by the molecular distribution and carbon isotopic composition of $n$-alkanes, Org. Geochem., 36, 363-370, 2005.

Meyers, P. A.: Applications of Organic geochemical proxies to paleolimnological reconstructions: a summary of examples from the Laurentian Great Lakes, Org. Geochem., 34, 261-289, 2003.

Meyers, P. A. and Ishiwatari, R.: Lacustrine Org. Geochem. - an overview of indicators of organic matter sources and diagenesis in lake sediments, Org. Geochem., 20, 867-900, 1993.

Neugebauer, I., Brauer, A., Dräger, N., Dulski, P., Wulf, S., Plessen, B., Mingram, J., Herzschuh, U., and Brande, A.: A Younger Dryas varve chronology from the Rehwiese palaeolake record in NE-Germany, Quaternary Sci. Rev., 36, 91-102, 2012.

Nichols, J. E., Booth, R. K., Jackson, S. T., Pendall, E. G., and Huang, Y.: Paleohydrologic reconstruction based on $n$-alkane distributions in ombrotrophic peat, Org. Geochem., 37, 1505$1513,2006$.

Ott, F., Wulf, S., Serb, J., Slowinski, M., Obremska, M., Tjallingii, R., Blaszkiewicz, M., and Brauer, A.: Constraining the time span between the Early Holocene Hässeldalen and Askja-S Tephras through varve counting in the Lake Czechowskie sediment record, Poland, J. Quaternary Sci., 31, 103-113, 2016.

Overbeck, F.: Botanisch-geologische Moorkunde unter besonderer Berücksichtigung der Moore Nordwestdeutschlands als Quellen zur Vegetations-, Klima- und Siedlungsgeschichte, Wachholtz, Neumünster, Germany, 1975.
Rach, O., Brauer, A., Wilkes, H., and Sachse, D.: Delayed hydrological response to Greenland cooling at the onset of the Younger Dryas in western Europe, Nat. Geosci., 7, 109-112, 2014.

Rach, O., Kahmen, A., Brauer, A., and Sachse, D.: A dualbiomarker approach for quantification of changes in relative humidity from sedimentary lipid $D / H$ ratios, Clim. Past, $13,741-$ 757, https://doi.org/10.5194/cp-13-741-2017, 2017.

Ralska-Jasiewiczowa, M., Van Geel, B., and Goslar, T.: The record of the Late Glacial/Holocene transition from the varved sediments of Lake Gosciąz (central Poland), Sveriges Geologiska Undersokning, 81, 257-268, 1992.

Rao, Z. G., Zhao, Y. W., Zhu, Y., Jia, G. D., and Henderson, A.: Is the maximum carbon number of long-chain $n$-alkanes an indicator of grassland or forest? Evidence from surface soils and modern plants, Chinese Sci. Bull., 56, 1714-1720, 2011.

Rasmussen, S. O., Andersen, K. K., Svensson, A. M., Steffensen, J. P., Vinther, B. M., Clausen, H. B., Siggaard-Andersen, M.L., Johnsen, S. J., Larsen, L. B., Dahl-Jensen, D., Bigler, M., Röthlisberger, R., Fischer, H., Goto-Azuma, K., Hansson, M. E., and Ruth, U.: A new Greenland ice core chronology for the last glacial termination, J. Geophys. Res.-Atmos., 111, 1-16, 2006.

Rasmussen, S. O., Bigler, M., Blockley, S. P., Blunier, T., Buchardt, S. L., Clausen, H. B., Cvijanovic, I., Dahl-Jensen, D., Johnsen, S. J., Fischer, H., Gkinis, V., Guillevic, M., Hoek, W. Z., Lowe, J. J., Pedro, J. B., Popp, T., Seierstad, I. K., Steffensen, J. P., Svensson, A. M., Vallelonga, P., Vinther, B. M., Walker, M. J. C., Wheatley, J. J., and Winstrup, M.: A stratigraphic framework for abrupt climatic changes during the Last Glacial period based on three synchronized Greenland ice-core records: refining and extending the INTIMATE event stratigraphy, Quaternary Sci. Rev., 106, 14-28, 2014.

Reimer, P. J., Bard, E., Bayliss, A., Beck, J. W., Blackwell, P. G., Ramsey, C. B., Buck, C. E., Cheng, H., Edwards, R. L., Friedrich, M., Grootes, P. M., Guilderson, T. P., Haflidason, H., Hajdas, I., Hatté, C., Heaton, T. J., Hoffmann, D. L., Hogg, A. L., Hughen, K. A., Kaiser, K. F., Kromer, B., Manning, S. W., Niu, M., Reimer, R. W., Richards, D. A., Scott, E. M., Southon, J. R., Staff, R. A., Turney C. S. M., and Van der Plicht, J.: IntCal13 and marine13 radiocarbon age calibration curves $0-50000$ years cal BP, Radiocarbon, 55, 1869-1887, 2013.

Renssen, H., Mairesse, A., Goosse, H., Mathiot, P., Heiri, O., Roche, D. M., Nisancioglu, K. H., and Valdes, P. J.: Multiple causes of the Younger Dryas cold period, Nat. Geosci., 8, 946950, 2015.

Rommerskirchen, F., Plader, A., Eglinton, G., Chikaraishi, Y., and Rullkötter, J.: Chemotaxonomic significance of distribution and stable carbon isotopic composition of long-chain alkanes and alkan-1-ols in C4 grass waxes, Org. Geochem., 37, 1303-1332, 2006.

Schenk, F., Väliranta, M., Muschitiello, F., Tarasov, L., Heikkilä, M., Björck, S., Brandefelt, J., Johansson, A. V., Näslund, J. O., and Wohlfahrt, B.: Warm summers during the Younger Dryas cold reversal, Nat. Commun., 9, 1634, https://doi.org/10.1038/s41467-018-04071-5, 2018.

Schlolaut, G., Brauer, A., Nakagawa, T., Lamb, H. F., Tyler, J. J., Staff, R. A., Marshall, M. H., Bronk Ramsey, C., Bryant, C. L., and Tarasov, P. E.: Evidence for a bi-partition of the Younger Dryas Stadial in East Asia associated with inversed cli- 
mate characteristics compared to Europe, Sci. Rep., 7, 44983, https://doi.org/10.1038/srep44983, 2017.

Schwark, L., Zink, K., and Lechterbeck, J.: Reconstruction of postglacial to early Holocene vegetation history in terrestrial Central Europe via cuticular lipid biomarkers and pollen records from lake sediments, Geology, 30, 463-466, 2002.

Słowiński, M.: Macrofossil reconstruction of preboreal wetland formed on dead ice block a case study of the Borzechowo mire in East Pomerania, Poland, Studia Quaternaria, 27, 3-10, 2010.

Słowiński, M., Błaszkiewicz, M., Brauer, A., Noryśkiewicz, B., Ott, F., and Tyszkowski, S.: The role of melting dead ice on landscape transformation in the early Holocene in Tuchola Pinewoods, North Poland, Quatern. Int., 388, 64-75, 2015.

Słowiński M., Zawiska, I., Ott, F., Noryśkiewicz, A. M., Plessen, B., Apolinarska, K., Lutyńska, M., Michczynska, D. J., Wulf, S., Skubała, P., Błaszkiewicz, M., and Brauer, A.: Differential lake system responses to late Allerød and early Younger Dryas climatic fluctuations recorded in varved sediments of the Trzechowskie palaeolake in Northern Poland (Central Europe), Quaternary Sci. Rev., 158, 94-106, 2017.

Street-Perrott, F. A., Ficken, K. J., Huang, Y. S., and Eglinton, G.: Late Quaternary changes in carbon cycling on Mt. Kenya, East Africa: an overview of the $\delta^{13} \mathrm{C}$ record in lacustrine organic matter, Quaternary Sci. Rev., 23, 861-879, 2004.

Uchikawa, J., Popp, B. N., Schoonmaker, J. E., and Zu, L.: Direct application of compound-specific radiocarbon analysis of leaf waxes to establish lacustrine sediment chronology, J. Paleolimnol., 39, 43-60, 2008.

Von Grafenstein, U., Erlenkeuser, H., Brauer, A., Jouzel, J., and Johnsen, S. J.: A mid-European decadal isotope-climate record from 15500 to 5000 years BP, Science, 284, 1654-1657, 1999.

von Grafenstein, U., Eicher, U., Erlenkeuser, H., Ruch, P., Schwander, J., and Ammann, B.: Isotope signature of the Younger Dryas and two minor oscillations at Gerzensee (Switzerland): palaeoclimatic and palaeolimnologic interpretation based on bulk and biogenic carbonates, Palaeogeogr. Palaeocl., 159, 215-229, 2000.
Wakeham, S. G.: A comparative survey of petroleum hydrocarbons in lake sediments, Mar. Pollut. Bull., 7, 206-211, 1976.

Wohlfarth, B., Blaauw, M., Davies, S. M., Andersson, M., Wastegård, S., Hormes, A., and Possnert, G.: Constraining the age of Lateglacial and early Holocene pollen zones and tephra horizons in southern Sweden with Bayesian probability methods, J. Quaternary Sci., 21, 321-334, 2006.

Wójcik, G. and Marciniak, K.: Opady atmosferyczne w regionie Dolnej Wisły wokresie 1951-1980, in: Uwarunkowania przyrodnicze i społeczno-ekonomiczne zagospodarowania Dolnej Wisły, edited by: Churski, Z., IG UMK, Toruń, Poland, 1993.

Woś, A.: Climate of Poland, Wydawnictwo Naukowe PWN, Warszawa, Poland, 1999.

Wulf, S., Ott, F., Słowiński, M., Noryśkiewicz, A. M., Dräger, N., Martin-Puertas, C., Czymzik, M., Neugebauer, I., Dulski, P., Bourne, A. J., Błaszkiewicz, M., and Brauer, A.: Tracing the Laacher See Tephra in the varved sediment record of the Trzechowskie palaeolake in central Northern Poland, Quaternary Sci. Rev., 76, 129-139, 2013.

Wulf, S., Drager, N., Ott, F., Serb, J., Appelt, O. Gudmundsdottir, E. R., van den Bogaard, C., Slowinski, M., Brauer, A., and Blaszkiewic, M.: Lateglacial and Holocene tephrostratigraphy of varved sediment records from Northern central European lowlands: first results from Lakes Tiefer See (NE Germany) and Czechowskie (N Poland), Quaternary Sci. Rev., 132, 1-14, 2016.

Zhang, Y., Togomura, Y., and Otsuki, K.: Study on the $n$-alkane patterns in some grasses and factors affecting the $n$-alkane patterns, J. Agric. Sci.-Cambridge, 142, 469-475, 2004.

Zhang, Z., Zhao, M., Eglinton, G., Lu, H., and Huang C. Y.: Leaf wax lipids as paleovegetational and paleoenvironmental proxies for the Chinese Loess Plateau over the last $170 \mathrm{kyr}$, Quaternary Sci. Rev., 25, 575-594, 2006. 